\title{
Failure criteria for porous dome rocks and lavas: a study of Mt. Unzen, Japan
}

\author{
Rebecca Coats $^{1}$, Jackie E. Kendrick ${ }^{1}$, Paul A. Wallace ${ }^{1}$, Takahiro Miwa ${ }^{2}$, Adrian J. Hornby ${ }^{1, a}$, James D. Ashworth ${ }^{1}$, \\ Takeshi Matsushima ${ }^{3}$, and Yan Lavallée ${ }^{1}$ \\ ${ }^{1}$ Department of Earth, Ocean and Ecological Sciences, University of Liverpool, Liverpool, L69 3GP, UK \\ ${ }^{2}$ National Research Institute for Earth Science and Disaster Prevention, Ibaraki, 305-0006, Japan \\ ${ }^{3}$ Institute of Seismology and Volcanology, Kyushu University, Nagasaki, 855 0843, Japan \\ a now at: Department of Earth and Environmental Sciences, Ludwig-Maximilians Universität München, \\ Munich, 80333, Germany
}

Correspondence: Rebecca Coats (r.coats@liverpool.ac.uk)

Received: 5 March 2018 - Discussion started: 26 March 2018

Revised: 9 October 2018 - Accepted: 15 October 2018 - Published: 8 November 2018

\begin{abstract}
The strength and macroscopic deformation mode (brittle vs. ductile) of rocks is generally related to the porosity and pressure conditions, with occasional considerations of strain rate. At high temperature, molten rocks abide by Maxwell's viscoelasticity and their deformation mode is generally defined by strain rate or reciprocally by comparing the relaxation timescale of the material (for a given condition) to the observation timescale - a dimensionless ratio known as the Deborah $(D e)$ number. Volcanic materials are extremely heterogeneous, with variable concentrations of crystals, glass-melt, and vesicles (of different sizes), and a complete description of the conditions leading to flow or rupture as a function of temperature, stress and strain rate (or timescale of observation) eludes us. Here, we examined the conditions which lead to the macroscopic failure of variably vesicular (0.09-0.35), crystal-rich ( $\sim 75$ vol \%), pristine and altered dome rocks (at ambient temperature) and lavas (at $900^{\circ} \mathrm{C}$ ) from Mt. Unzen volcano, Japan. We found that the strength of the dome rocks decreases with porosity and is commonly independent of strain rate; when comparing pristine and altered rocks, we found that the precipitation of secondary mineral phases in the original pore space caused minor strengthening. The strength of the lavas (at $900^{\circ} \mathrm{C}$ ) also decreases with porosity. Importantly, the results demonstrate that these dome rocks are weaker at ambient temperatures than when heated and deformed at $900^{\circ} \mathrm{C}$ (for a given strain rate resulting in brittle behaviour). Thermal stressing (by heating and cooling a rock up to $900^{\circ} \mathrm{C}$ at a rate of
\end{abstract}

$4{ }^{\circ} \mathrm{C} \mathrm{min}-1$, before testing its strength at ambient temperature) was found not to affect the strength of rocks.

In the magmatic state $\left(900^{\circ} \mathrm{C}\right)$, the rheology of the dome lavas is strongly strain rate dependent. Under conditions of low experimental strain rate $\left(\leq 10^{-4} \mathrm{~s}^{-1}\right)$, ductile deformation dominated (i.e. the material sustained substantial, pervasive deformation) and displayed a non-Newtonian shear thinning behaviour. In this regime, the apparent viscosities of the dome lavas were found to be essentially equivalent, independent of vesicularity, likely due to the lack of pore pressurisation and efficient pore collapse during shear. At high experimental strain rates $\left(\geq 10^{-4} \mathrm{~s}^{-1}\right)$ the lavas displayed an increasingly brittle response (i.e. deformation resulted in failure along localised faults); we observed an increase in strength and a decrease in strain to failure as a function of strain rate. To constrain the conditions leading to failure of the lavas, we analysed and compared the critical Deborah number at failure $\left(D e_{\mathrm{c}}\right)$ of these lavas to that of pure melt $\left(D e_{\text {melt }}=10^{-3}-10^{-2}\right.$; Webb and Dingwell, 1990). We found that the presence of crystals decreases $D e_{\mathrm{c}}$ to between $6.6 \times 10^{-4}$ and $1 \times 10^{-4}$. The vesicularity $(\varphi)$, which dictates the strength of lavas, further controls $D e_{\mathrm{c}}$ following a linear trend. We discuss the implications of these findings for the case of magma ascent and lava dome structural stability. 


\title{
多孔質な岩石及び溶岩の破壊基準：雲仙火山溶岩ドームでの研究
}

\author{
マグマ(溶岩)と岩石のレオロジーと強度は, 応力の蓄積と散逸を支配し, 噴火様式や山体の構造的安定性に影響 \\ を与える. 火山噴出物は極端に不均質であり, 様々な量・サイズの結晶, ガラス(メルト),気泡を含む. そのため \\ ，温度·応力・歪速度の関数として，その流れや亀裂形成を引き起こす状態を完全に記載することは難しい，こ \\ こで我々は，雲仙火山において溶岩ドームを形成し様々な発泡度 $(9-35 \%)$ を有する高結晶度 $($ ～75\%)な岩石(常温) \\ と溶岩(900度)について, その破壊を引き起こす状態を検討した. その結果, 我々は岩石の強度は空隙率とともに \\ 減少し，歪速度に依存しないことを発見した： 新鮮な岩石と変質したものでは, 後者でわずかに強度が大きい \\ また，溶岩 $\left(900^{\circ} \mathrm{C}\right)$ の強度も空隙率とともに減少する. この結果は重要なことに, 脆性的振る舞いを起こす歪 \\ 速度において, 常温における岩石の強度は, それを $900^{\circ} \mathrm{C}$ ま゙加熱し変形させたときの強度よりも弱いことを示 \\ している．このとき， 熱応力は岩石の強度に影響を与えない． \\ 高温条件 $\left(900^{\circ} \mathrm{C}\right)$ では，溶岩のレオロジーは歪速度に強く依存する. 低歪速度下 $\left(<10^{-4} \mathrm{~s}^{-1}\right)$ では, 溶岩は塑性的に振 \\ る舞い(物質が広範な固体変形を持続させる), 非ニュートン流体としてずり粘減の振る舞いを示した。 このレジ \\ 一ムでは, 溶岩の見かけ粘性は, おそらく剪断時の効率的な空隙崩壊のため, 発泡度に依存しない. 高歪速度下 \\ $\left(>10^{-4} \mathrm{~s}^{-1}\right)$ では, 溶岩は益々の脆性的な応答(局所的な断層に沿った破壊による変形)を示す; 歪速度の関数として, \\ 強度の増加と破壊へ至るときの歪の減少が観察された，溶岩の破壊を引き起こす状態を制約するため，これら溶 \\ 岩における破壊時の臨界デボラ数 $\left(\mathrm{De}_{\mathrm{c}}\right.$, 緩和時間と実験観察時間の比)を解析し, メルトにおけるそれ $\left(\mathrm{De}_{\mathrm{melt}},=10^{-3}-\right.$ \\ 10-2; Webb \& Dingwell, 1990)と比較した. 我々は結晶の存在がDecを $6.6 \times 10^{-4}-1 \times 10^{-4}$ まで減少させることを発見し \\ た. またさらに，溶岩の強度に影響する発泡度 $(\varphi)$ も $\mathrm{De}_{\mathrm{c}}$ を線形傾向のようにコントロールする. 我々はこれらの \\ 発見が与える，マグマ上昇と溶岩ドームの構造的安定性への示唆を議論する.
}

\section{Introduction}

\subsection{Lava dome eruptions}

Magma ascends to the Earth's surface and erupts through a wide spectrum of eruptive style (e.g. Siebert et al., 2015), which contributes to the construction of different volcanic edifices (e.g. de Silva and Lindsay, 2015). Amongst this activity, lava domes form when viscous magma accumulates and creates mounds of rocks and lava above the vent (Sparks, 1997; Fink and Anderson, 2000). These domebuilding events make up approximately $6 \%$ of volcanic eruptions worldwide (Calder et al., 2015) and their characteristics are governed by the rheology of the erupted magmas (Gonnermann and Manga, 2007; Lavallée et al., 2007). The emplacement of lava domes may be endogenous or exogenous, whether growing through inflation from within or through the piling up of discrete extrusive bodies (Hale and Wadge, 2008). In some extreme cases the latter can manifest as lava spines that extrude in a near-solid state (Heilprin, 1903; Stasiuk and Jaupart, 1997; Young et al., 1998; Tanguy, 2004; Scott et al., 2008; Vallance et al., 2008; Kendrick et al., 2012; Cashman and Sparks, 2013). Dome eruptions can produce a range of primary hazards, from ash fall to large-scale pyroclastic density currents, generated by gravitational collapse (e.g. Sparks and Young, 2002). They also have the potential to generate secondary hazards such as lahars (e.g. Nevado del Ruiz, Colombia; Pierson et al., 1990), edifice failure induced by magma intrusions (Voight and Elsworth, 1997; Reid et al., 2010) and lava dome collapse, as the mass cools or redistributes (e.g. Elsworth and Voight, 1996). In seismically active areas, strong tectonic earthquakes can both initiate activity and promote structural instability (e.g. Mayuyama, Japan; Siebert et al., 1987), even in long-dormant systems (e.g. Merapi, Indonesia; Surono et al., 2012). The eruption, emplacement and stability of lava domes reflects the mechanical properties of their constituent materials; thus, it is essential that the evaluation of monitoring data and development of improved hazard forecasting tools at lava dome volcanoes be based on a description of the mechanical and rheological properties of the materials.

\subsection{Lava dome rheology}

The rheology of silicate melts has been explored extensively (e.g. Dingwell and Webb, 1989, 1990; Webb and Dingwell, 1990; Webb and Knoche, 1996; Fluegel, 2007; Giordano et al., 2008; Cordonnier et al., 2012b). Dingwell and Webb (1989) demonstrated that silicate liquids are viscoelastic bodies, which abide by the glass transition - a temperature-time space that defines their struc- 
tural relaxation according to the theory of viscoelasticity of Maxwell (1867). Maxwell's work established that the structural relaxation timescale $\tau$ equals the ratio between the melt viscosity $\eta_{\mathrm{m}}$ (in Pas) and its elastic modulus at infinite frequency $G_{\infty}$ (in Pa) according to

$\tau=\eta_{\mathrm{m}} / G_{\infty}$.

Dingwell and Webb (1989) compiled information for different silicate liquids and showed that $G_{\infty}$ is essentially invariant and approximately $10^{10 \pm 0.5} \mathrm{~Pa}$ in the temperature range of interest for magmatic systems. Thus, the relaxation timescale of silicate melts can simply be related to their viscosity at a given temperature. Extensive experimental efforts in the community have resulted in the creation of a complete non-Arrhenian model for silicate melt viscosity, as a function of composition and temperature (e.g. Giordano et al., 2008). The concept of viscoelasticity and relaxation timescale can therefore be applied to a range of volcanic processes.

Viscoelasticity dictates the behaviour of a magma. A rheological description of viscoelastic materials may be cast via the non-dimensional Deborah number, De (e.g. Reiner, 1964), which is defined by a ratio between Maxwell's relaxation timescale, $\tau$ (Eq. 1), and the timescale of observation, $t_{\text {obs: }}$ :

$D e=\frac{\tau}{t_{\mathrm{obs}}}$.

This relationship states that under observation timescales longer than the relaxation timescale (for a given melt viscosity), a melt may flow like a liquid; but at short observation timescales, a melt may behave as a solid (like a glass). In such a kinetic framework, increasing the temperature reduces the viscosity and therefore the time required for structural relaxation. As the relaxation timescale is inversely proportional to the structural relaxation rate, it can thus be said that the structural relaxation rate defines the transition between the liquid and solid states (commonly referred to as the glass transition, $T_{\mathrm{g}}$ ). Dingwell and Webb (1990) demonstrated that at $D e<10^{-3}$, a silicate melt can be described as a Newtonian fluid. However, when silicate melts are deformed at higher rates at which the observation timescale is short, $10^{-3}<D e<10^{-2}$, the melt structure accumulates damage upon deformation, which results in an apparent nonNewtonian behaviour. At $D e>10^{-2}$, silicate melts undergo the glass transition and ruptures (Dingwell and Webb, 1990; Wadsworth et al., 2017); this is known as the critical Deborah number, $D e_{\mathrm{c}}-$ a criteria met in several eruptive scenarios, including fragmentation and explosive eruptions (e.g. Dingwell, 1996).

During transport and eruption, magmas crystallise and volatiles are exsolved (e.g. Cashman, 1992; Martel and Schmidt, 2003), resulting in magmatic suspensions, undergoing significant rheological changes (e.g. Lejeune and Richet, 1995; Barmin et al., 2002). In particular, dome-building eruptions have been observed to produce variably vesicular (generally $0-\sim 0.40$ ) and crystalline (e.g. $0-100$ vol \%) lavas (Castro et al., 2005; Mueller et al., 2005, 2011a; Lavallée et al., 2007; Pallister et al., 2008; Cordonnier et al., 2009; Calder et al., 2015; Heap et al., 2016a). The addition of crystals to a melt increases the effective viscosity (Lejeune and Richet, 1995). At a moderate crystal fraction (below $\sim 25 \mathrm{vol} \%$ ) this can be approximated by the EinsteinRoscoe equation (Einstein, 1911; Roscoe, 1952) and variations thereof (see Mader et al., 2013, and references therein). When particle concentrations reach a critical fraction that promotes interaction (typically $\leq 0.25$, depending on crystal morphology; Mader et al., 2013), the suspension becomes non-Newtonian (Deubelbeiss et al., 2011). Experiments on dome lavas at high temperature have shown that the apparent viscosity of these suspensions decreases with strain rate (Lavallée et al., 2007; Avard and Whittington, 2012) - a shear thinning effect influenced by crystal alignment and interaction (Vona et al., 2011), crystal plasticity (Kendrick et al., 2017) and fracture processes (Lavallée et al., 2008; Kendrick et al., 2013b). The addition of a separate gas phase to a magma adds further rheological complexity (Lejeune et al., 1999), serving to increase or decrease viscosity depending upon the volume fraction of bubbles, pore pressure, the initial viscosity of the melt, the amount of deformation they are subjected to (e.g. Manga et al., 1998; Llewellin and Manga, 2005) and pore connectivity, which may promote outgassing and pore compaction (e.g. Ashwell et al., 2015). Bubbles will affect the viscosity of the suspension depending on their capillary number, $\mathrm{Ca}$, a dimensionless ratio of the deforming viscous stress over the restoring stress from surface tension. A more spherical bubble will generally have a low $\mathrm{Ca}$, as restoring stresses dominate, and will behave as a barrier which fluid flow will have to deviate around, resulting in an increased viscosity of the suspension. Conversely, an elongate bubble generally has a high $\mathrm{Ca}$, as deforming stresses dominate, and may act as a free slip surface, causing a decrease in the suspension viscosity (e.g. Manga et al., 1998; Mader et al., 2013). Three-phase models, although less explored than two-phase flows, have been modelled by Truby et al. (2015) by combining two sets of two-phase equations. Despite the aforementioned rheological studies focused on the viscosity of magmatic suspensions, the conditions leading to failure of such magmatic suspensions have received less attention. Following the work of Lavallée et al. (2007), Gottsmann et al. (2009) showed that the presence of crystals may reduce the strain rate required to rupture magma (if one were to consider the melt relaxation rate) to conditions in which $D e<10^{-2}$, and Lavallée et al. (2008) and Gottsmann et al. (2009) showed that brittle processes may be active at conditions 2 orders of magnitude lower than such a purely brittle limit. Cordonnier et al. (2012a) explored the effect of crystallinity on magma rupture, showing that $D e$ indeed decreases with crystallinity. However, here we note that when determining the Deborah number for their experimental find- 
ings, the relaxation timescale was calculated using the apparent viscosity of the suspension rather than the viscosity of the interstitial melt, which is the basis for the applicability of viscoelasticity in this scenario (this will be discussed further in Sect. 5.2). Important questions remain as to the contribution of vesicles on the rupture of magmas, as the strength of geomaterials in the brittle field is generally described in terms of porosity (e.g. Paterson and Wong, 2005, and references in Sect. 1.3).

\subsection{Lava dome mechanics}

Various numerical models have been developed to evaluate the structural stability of lava domes and, with sufficient knowledge of a volcanic edifice and the properties of the materials it holds, collapse events can be modelled effectively (e.g. Elsworth and Voight, 1996). Although elegant and complex, these simulations tend to make non-trivial assumptions regarding vent geometry, dome morphology, and material properties (e.g. Ball et al., 2015). Volcanic domes are composed of materials with a vast spectrum of heterogeneities and degree of coherence (Mueller et al., 2011b; Lavallée et al., 2012, 2018) and although assigning fixed values for the material properties of dome rocks may be computationally beneficial, accounting for the wide range of physical and mechanical properties of dome materials remains a great source of uncertainty. Mechanical testing can be carried out to resolve the behaviour of rocks (see Paterson and Wong, 2005, and references therein) and this has resulted in a recent surge in laboratory testing to advance the understanding of the tensile strength, compressive strength, frictional coefficient and flow behaviour of these heterogeneous dome rocks and magmas as a function of temperature and stresses or strain rates (Smith et al., 2007, 2011; Lavallée et al., 2007; Hess et al., 2008; Kendrick et al., 2012, 2013b, a; Kolzenburg et al., 2012; Heap et al., 2014a; Hornby et al., 2015; Lamb et al., 2017; Lamur et al., 2017, and more.)

The uniaxial compressive strength (USC) of volcanic rocks has been found to inversely correlate with porosity (AlHarthi et al., 1999; Kendrick et al., 2013b; Heap et al., 2014a, b, 2016b; Schaefer et al., 2015) and to positively correlate with strain rate (Schaefer et al., 2015). In volcanic rocks, porosity is made up of vesicles and microfractures, which contribute to the mechanical behaviour and strength of the rock (Sammis and Ashby, 1986; Ashby and Sammis, 1990; Heap et al., 2014a; Bubeck et al., 2017; Collombet et al., 2017; Griffiths et al., 2017). Two models have gained traction to explain the strength of rocks. The pore-emanating crack model of Sammis and Ashby (1986) describes the case of a pore-only system in which cracks nucleate from the pores and propagate in the direction parallel to the principal stress, when the applied stress overcomes the fracture toughness of a rock. As the applied stress increases, the microfractures propagate and coalesce, leading to macroscopic failure. An analytical estimation of this model was derived by Zhu et al. (2010) to estimate the uniaxial compressive stress $(\sigma)$ of a sample, with a pore radius $(r)$, as a function of its porosity $(\varphi)$ and the fracture toughness $\left(K_{\mathrm{IC}}\right)$ :

$\sigma=\frac{1.325}{\varphi^{0.414}} \frac{K_{\mathrm{IC}}}{\sqrt{\pi r}}$.

In contrast, the sliding wing-crack model of Ashby and Sammis (1990) considers only pre-existing microfractures inclined from the principal stress direction. The model describes that first the frictional resistance of the crack must be overcome before wing cracks can form, and then the fracture toughness must be overcome for them to propagate and interact. The analytical approximation for this model was developed by Baud et al. (2014):

$\sigma=\frac{1.346}{\sqrt{1+\mu^{2}-\mu}} \frac{K_{\mathrm{IC}}}{\sqrt{\pi c}} D_{0}^{-0.256}$,

where $\mu$ is the friction coefficient of the crack, $c$ is the halflength of a pre-existing crack, and $D_{0}$ is an initial damage parameter (which takes into consideration the number of cracks per unit area and their angle with respect to the principal stress).

Heap et al. (2014a) experimentally demonstrated that neither model fully satisfied the mechanical data obtained for volcanic rocks and suggested that a microstructural model that combines the two mechanisms must be developed to permit the design of simulations considering the mechanical behaviour of microstructurally complex volcanic materials.

The problem of lava dome stability does not simply require knowledge of hot lavas or cold rocks; it further requires understanding of the effects of temperature (e.g. Harris et al., 2002), chemical alteration (e.g. Lopez and Williams 1993; Ball et al., 2015), pore pressure (Farquharson et al., 2016), thermal stressing (Heap et al., 2009, 2010, 2014a; Kendrick et al., 2013a; Schaefer et al., 2015) and mechanical stressing at different rates such as during seismic shaking (e.g. Cole et al., 1998; Voight, 2000; Calder et al., 2002) or magmatic intrusions (Walter et al., 2005) on the mechanical properties of the materials, many aspects of which have been tested in the context of edifices. The cooling of crystalline lava bodies results in the generation of fractures (Fink and Anderson, 2000; Takarada et al., 2013; Eggertsson et al., 2018; Lamur et al., 2018) - leaving a highly fractured blocky mass, the mechanical impact of which is difficult to quantify (Voight, 2000; Voight and Elsworth, 2000). Furthermore, thermal stressing cycles that could result from proximity of hot magma in a conduit, lava dome or edifice following a new eruptive episode have been found to only weakly modify the strength of commonly microfractured volcanic rocks (Heap et al., 2009; Kendrick et al., 2013a; Schaefer et al., 2015), unless they contain thermally liable minerals. Recent experiments on porous basalt by Eggertsson et al. (2018) have shown that rocks that are essentially void of microcracks (likely due to slow cooling), are however susceptible 

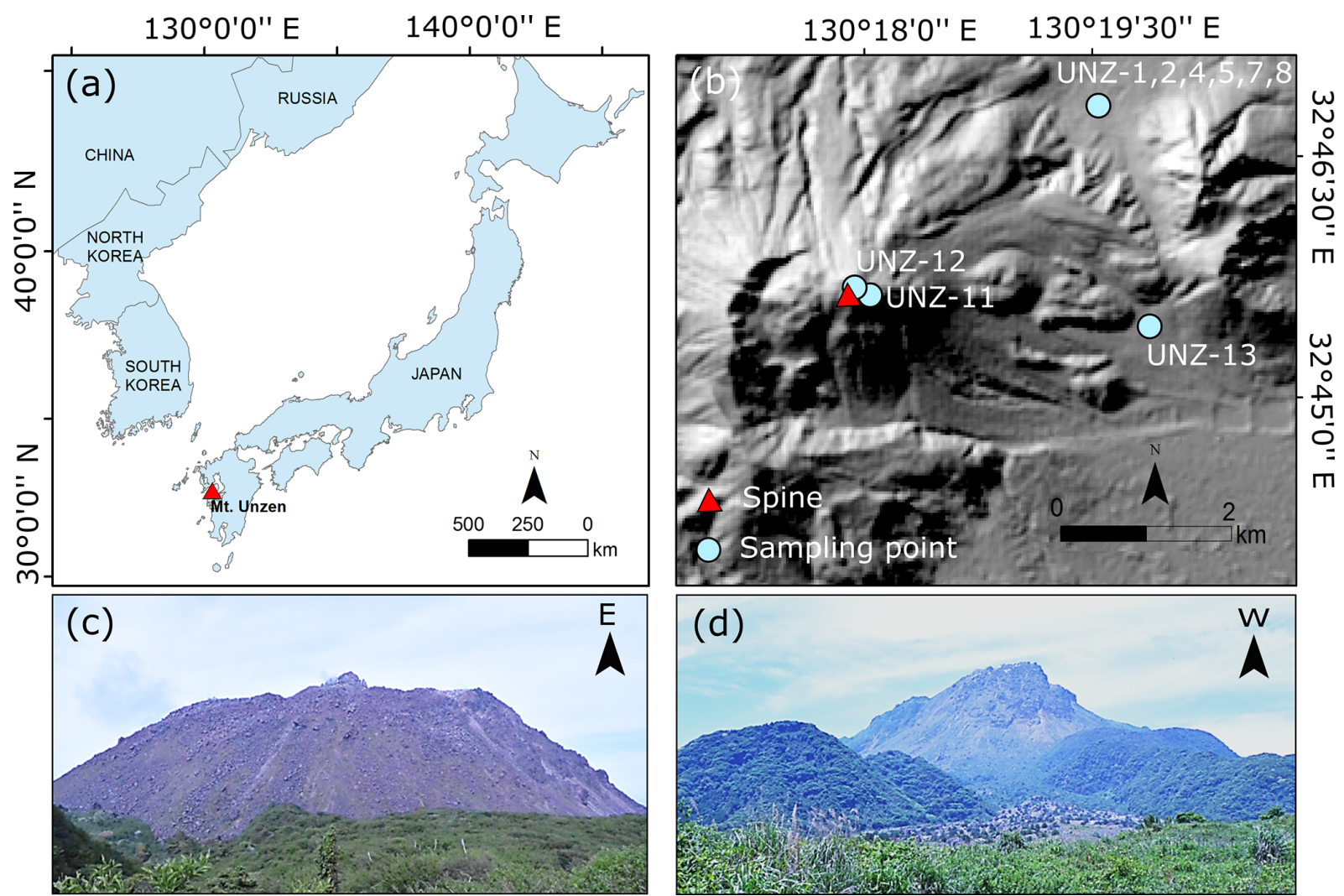

Figure 1. (a) Location of Mt. Unzen in south-western Japan; (b) sample collection locations and location of the erupted spine, the summit of Mt. Unzen at $1500 \mathrm{~m}$ above sea level (NASA/METI/AIST/Japan Space Systems, 2001); view of Mt. Unzen lava dome looking east $\sim 0.62 \mathrm{~km}$ from the spine (c) and west $\sim 3.87 \mathrm{~km}$ from the spine (d) in 2016 .

to fracture damage by thermal stressing (i.e. forming cooling joints); in contrast, microfractured rocks may not necessarily accumulate more damage during cooling; yet upon contraction, pre-existing fracture may widen to give way to the ingression of hydrothermal fluids (e.g. Lamur et al., 2018), further contributing to the stress balance and mechanical response.

\subsection{Mt. Unzen lava dome}

The Unzendake volcanic complex is situated on the Shimabara Peninsula in south-western Japan (Fig. 1a). The volcanic complex began to grow at $0.5 \mathrm{Ma}$ and now covers $20 \mathrm{~km}(\mathrm{E}-\mathrm{W})$ by $25 \mathrm{~km}(\mathrm{~N}-\mathrm{S})$ (Takarada et al., 2013). Unzendake exhibits an intricate eruptive history of lava domes, flows and pyroclastic deposits (Nakada and Fujii, 1993) of predominantly dacitic composition (Nakada and Motomura, 1999).

On 17 November 1990, after 198 years of quiescence, a phreatic eruption occurred at Mt. Unzen, which was accompanied by multiple earthquake swarms (Matsushima and Takagi, 2000). This was followed shortly afterwards by a phreatomagmatic eruption along with intense edifice swelling, and on 20 May 1991, the extrusion of a lava spine initiated the growth of the Heisei-Shinzan dome complex (Nakada and Fujii, 1993; Takarada et al., 2013). This introduced a 45-month-long period of lava dome activity with growth being primarily exogenous in periods of high extrusion rate and endogenous in times of low effusion rate (Nakada et al., 1995, 1999). The final stage of growth was marked by the extrusion of a spine between October 1994 and February 1995 (which can be seen today; Fig. 1b-c), characterised by pulsatory ascent and seismicity (Umakoshi et al., 2008; Lamb et al., 2015), along fault zones defined by compactional shear and mineral reactions, crystal plasticity and comminution (Wallace et al., 2017). The end of the eruption was followed by cooling of the lava dome and thermal contraction that caused multiple joints (Takarada et al., 2013). Fumarole activity has continued to the present day, with temperatures decreasing from $300^{\circ} \mathrm{C}$ in mid-2007 to $90^{\circ} \mathrm{C}$ in 2011 (Takarada et al., 2013).

In total, 13 lava lobes were formed, and, at its maximum size, the lava dome was $1.2 \mathrm{~km}(\mathrm{E}-\mathrm{W})$ by $0.8 \mathrm{~km}(\mathrm{~N}-\mathrm{S})$ wide. In particular lobe 11, which dominated the eastern side of the complex (Nakada et al., 1995, 1999), has long been unstable, which has led to partial collapses that generated several pyroclastic density currents (PDCs; Nakada et al., 1999; Sakuma et al., 2008). The flows were estimated to have travelled at 
$200 \mathrm{~km} \mathrm{~h}^{-1}$, up to $5.5 \mathrm{~km}$ down the Oshigadani Valley (Yamamoto et al., 1993; Takarada et al., 2013). All in all, pyroclastic flows buried and/or burned approximately 800 buildings, with debris flows destroying a further $\sim 1700$, and in the summer of 1991 the number of evacuated persons exceeded 11000 (Nakada et al., 1999). The Committee of Survey and Countermeasure on Lava Dome Collapse at Mt. Unzen advises that the risk of collapse of lobe 11 is high; an exclusion zone remains active to the $\mathrm{E}$ of the summit and access to the lava dome is strictly limited. Data from electrooptical distance measuring instruments suggest that lobe 11 has advanced $1 \mathrm{~m}$ in 14 years (measurements from 19972011), and recent observations from ground-based synthetic aperture radar show the development of a shear fracture (Kohashi et al., 2012). Therefore, the complete or partial collapse of the lobe and the generation of block-and-ash flows are likely hazards, particularly after large regional earthquakes. The current uncertainty regarding the structural stability of the dome at Mt. Unzen, particularly after seismic activity, has led to recent field campaigns and mechanical studies of the dome material (e.g. Cordonnier et al., 2009; Hornby et al., 2015). The destabilisation of lava domes due to tectonic activity is essentially a superficial process, meaning the stress balance may be considered a uniaxial problem and tested as such (e.g. Quane and Russell, 2005).

\section{Materials and methods}

\subsection{Sample selection}

Mt. Unzen lava dome is made up of porphyritic, dacite $\left(\sim 63 \mathrm{wt} \% \mathrm{SiO}_{2}\right.$ ) lava blocks which typically have large (> $3 \mathrm{~mm}$ ) and abundant (> $25 \mathrm{vol} \%$ ) plagioclase phenocrysts, along with fewer numbers of amphibole $(\sim 5 \mathrm{vol} \%)$, biotite $(\sim 2 \mathrm{vol} \%)$ and quartz $(\sim 2 \mathrm{vol} \%)$ phenocrysts and microphenocrysts set in a partially crystalline $(\sim 50 \mathrm{vol} \%)$ groundmass of plagioclase, pyroxene, quartz pargasite and Fe-Ti oxides in a rhyolitic interstitial glass (Nakada and Motomura, 1999; Wallace et al., 2017). However, as the dome was formed through both exogenous and endogenous growth the petrological history of the eruptive products varies widely and as such the microstructure of the blocks forming the dome varies considerably. Furthermore, lasting heat sources and ongoing fumarolic activity have led to local thermal and hydrothermal alteration of the dome (Almberg et al., 2008). This heterogeneity calls for a variable sample suite to represent the dome material and to constrain the processes of deformation and cooling that occurred throughout lava dome formation, which influences its current structural stability.

In this study, nine samples were selected with different properties. Samples UNZ-1, UNZ-2, UNZ-4, UNZ-5, UNZ7 and UNZ-8 were collected from easily accessible June 1993 block-and-ash flow deposits in the Minami-Senbongi area, north-east of the spine; UNZ-13 was collected from the
May-August 1991 deposits in the restricted area of the Mizunashi River, east of the spine (see Fig. 1b). These rocks were collected as they represent the freshest (unaltered) materials that originate from dome collapse events during eruption, prior to any chemical alteration (e.g. Cordonnier et al., 2009). Sample UNZ-11 was collected on lobe 11 of the dome, selected as it showed signs of hydrothermal alteration (crusted, white and friable). UNZ-12 was collected on the dome, just east of the lava spine, and was chosen specifically for its reddish colour which suggested thermal alteration and oxidation. Each sample block was then cored to make multiple $20 \mathrm{~mm}$ diameter cylindrical cores, cut and then ground parallel to $40 \mathrm{~mm}$ in length (Fig. S1 in the Supplement) to maintain a $2: 1$ aspect ratio in accordance with the ISRM suggested method (ISRM Turkish National Group, 2015).

\subsection{Sample characterisation and preparation}

\subsubsection{Geochemistry}

The bulk geochemical compositions of selected samples were determined using a Panalytical Axios advanced x-ray fluorescence spectrometer (XRF) at the University of Leicester (using fused glass beads prepared from ignited powders). Sample-to-flux ratio was kept at $1: 5,80 \% \mathrm{Li}$ metaborate: $20 \% \mathrm{Li}$ tetraborate flux. Results are quoted as component oxide weight percent and recalculated to include LOI (loss on ignition).

The geochemical composition of the interstitial glass in sample block UNZ-4 was determined using a Cameca SX-5 field emission electron probe microanalyser (EPMA) at the University of Oxford. A variety of standards were used to calibrate the spectrometers, including wollastonite for $\mathrm{Ca}$, and albite for $\mathrm{Al}, \mathrm{Na}$ and Si. Secondary reference standards, of which the exact chemistry was known, were utilised for better precision and accuracy. These were labradorite and kn18 glass (comendite obsidian, Kenya), used as the chemistries were similar to those of the Mt. Unzen glass sample. Analyses used an accelerating voltage of $15 \mathrm{KeV}$, a beam current of $6 \mathrm{nA}$ and a defocussed spot size of $10 \mu \mathrm{m}$. The data were checked for major element oxides' totals.

\subsubsection{Porosity}

The porosity and character of the pores (i.e. whether connected or isolated) was assessed using an AccuPyc 1340 helium pycnometer from Micromeritics. Firstly, height $(h$; in metres), radius ( $r$; in metres) and mass ( $m$; in kilograms) were recorded for each cylindrical core sample, providing a constraint on sample density $\left(\rho_{\mathrm{s}}\right.$; in kilograms per cubic metre):

$\rho_{\mathrm{s}}=m / \pi r^{2} h$.

Secondly, the solid density of the rocks $\left(\rho_{0}\right)$ was constrained by measuring the mass and volume of a powdered lump from 
each rock with a pycnometer; from these measurements, the total porosity of each rock could be estimated via

$\varphi_{\mathrm{T}}=1-\left(\rho_{\mathrm{s}} / \rho_{0}\right)$.

To constrain the fraction of isolated pores in the rocks, the skeletal volume ( $V_{\text {skeletal }}$; in cubic metres) of each core was measured with the pycnometer. The porosity connected to the outside of the sample (henceforth termed connected porosity), $\varphi_{\mathrm{c}}$, could then be calculated via

$\varphi_{\mathrm{c}}=1-\left(V_{\text {skeletal }} / \pi r^{2} h\right)$,

and isolated porosity, $\varphi_{\mathrm{i}}$, via

$\varphi_{\mathrm{i}}=\varphi_{\mathrm{T}}-\varphi_{\mathrm{c}}$

The porosity determination was used to omit outliers from any sample block to ensure that the rocks of a given porosity were tested and compared to one another.

\subsubsection{Microstructures}

Thin sections of UNZ-4, UNZ-11, UNZ-12 and UNZ-13 were prepared with a fluorescent dyed epoxy, selected as they cover a vast range of sample diversity, including both the lower and upper bounds of porosity, and collection site. Images were acquired using a DM2500P Leica microscope in plane-polarised light. To further constrain the microstructures of each sample block, backscattered electron (BSE) images were taken of each sample using a Philips XL 30 tungsten filament scanning electron microscope (SEM), equipped with an energy-dispersive X-ray spectrometer (EDS), and a Hitachi TM3000 SEM at the University of Liverpool. Stubs of the samples were set in epoxy, polished and carbon coated before being imaged in the Philips XL30 at a working distance of $13 \pm 0.1 \mathrm{~mm}$ using $20 \mathrm{kV}$ beam voltage, a $60-90 \mu \mathrm{A}$ beam current and a spot size of 5. Thin sections of the samples were imaged with the Hitachi TM3000 using a $15 \mathrm{kV}$ beam and $10 \mathrm{~mm}$ working distance.

\subsubsection{Thermal analysis}

To constrain the conditions at which to carry out the hightemperature uniaxial tests, we evaluated the softening point of the Mt. Unzen dome rock using a Netzsch 402 F1 Hyperion thermomechanical analysis (TMA) at the University of Liverpool. Under a $20 \mathrm{~mL} \mathrm{~min}^{-1}$ argon flow, a $6.37 \mathrm{~mm}$ tall, $5.87 \mathrm{~mm}$ wide cylindrical sample of UNZ-8 was placed under a constant load of $3 \mathrm{~N}$ and heated at $10^{\circ} \mathrm{C} \mathrm{min}^{-1}$ to $1100^{\circ} \mathrm{C}$. The softening point of the material was found as the temperature at which the applied load counteracts sample expansion by inducing viscous flow (and sample shortening) during heating. This was detected at $824.6^{\circ} \mathrm{C} 80.6 \mathrm{~min}$ into the measurement (Fig. S5). An experimental temperature of $900{ }^{\circ} \mathrm{C}$ was selected as, being well above the softening point, this is high enough to allow for flow to occur

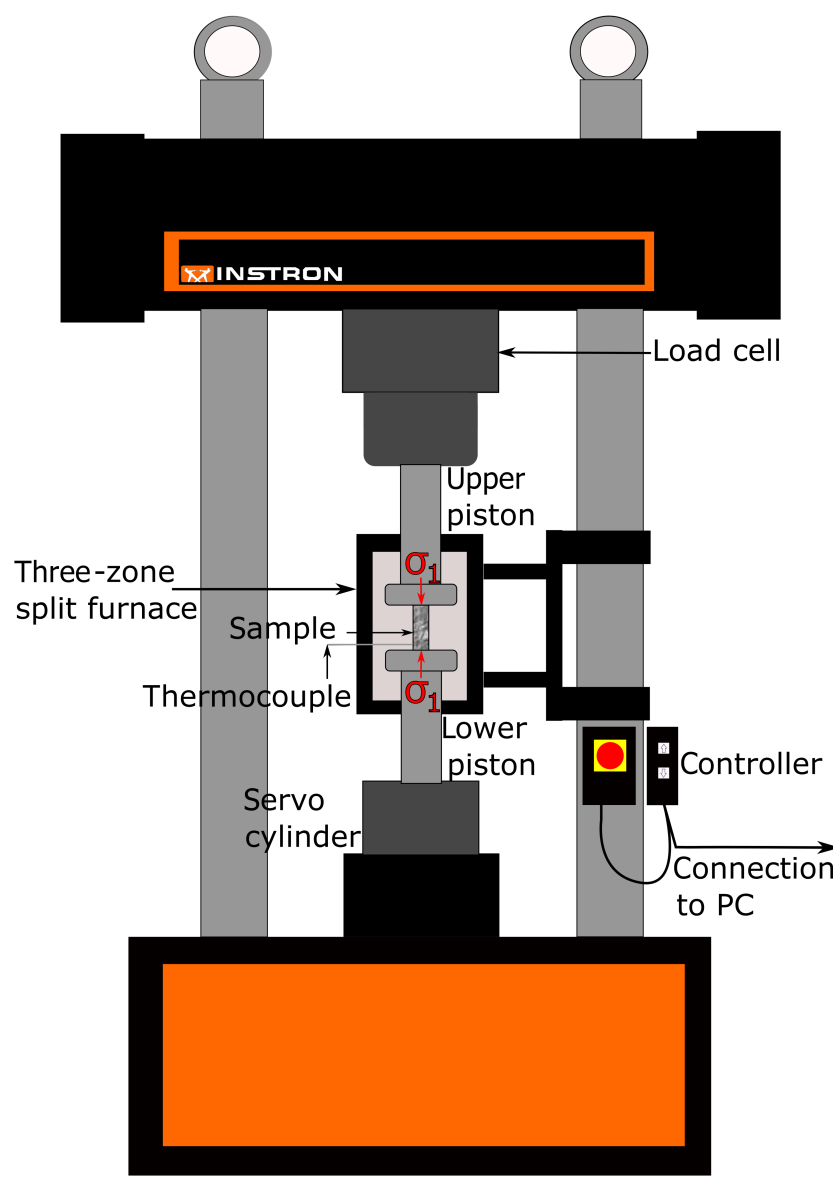

Figure 2. Schematic of the USC testing set-up in the Experimental Volcanology and Geothermal Research Laboratory at the University of Liverpool. A $100 \mathrm{kN}$ Instron 8862 uniaxial press with a three-zone, split cylinder furnace was used to perform experiments at varying strain rates and temperatures.

on the timescales under investigation. This chosen temperature is close to the magmatic temperature $\left(850-870^{\circ} \mathrm{C}\right)$ constrained to have followed mixing (Venezky and Rutherford, 1999) and above the glass transition of Unzen spine material $\left(790^{\circ} \mathrm{C}\right)$ measured by differential scanning calorimetry at a rate of $10^{\circ} \mathrm{C} \mathrm{min}^{-1}$ (Wallace et al., 2017), though the temperature profile within the conduit and dome during emplacement is poorly constrained.

\subsubsection{Thermal stressing}

Selected cores of pristine material were thermally stressed in a Carbolite box furnace to examine the effects of experimentally induced heating-cooling cycles on the residual strength of rock cores. Cores were subjected to heating at $4{ }^{\circ} \mathrm{C} \mathrm{min}-1$ followed by $1 \mathrm{~h}$ dwell at $900 \pm 3^{\circ} \mathrm{C}$ (sample temperature) and cooling at $4{ }^{\circ} \mathrm{C} \mathrm{min}^{-1}$. The density and porosity of each sample were measured before and after thermal stressing, and the products were further subjected to USC tests. 


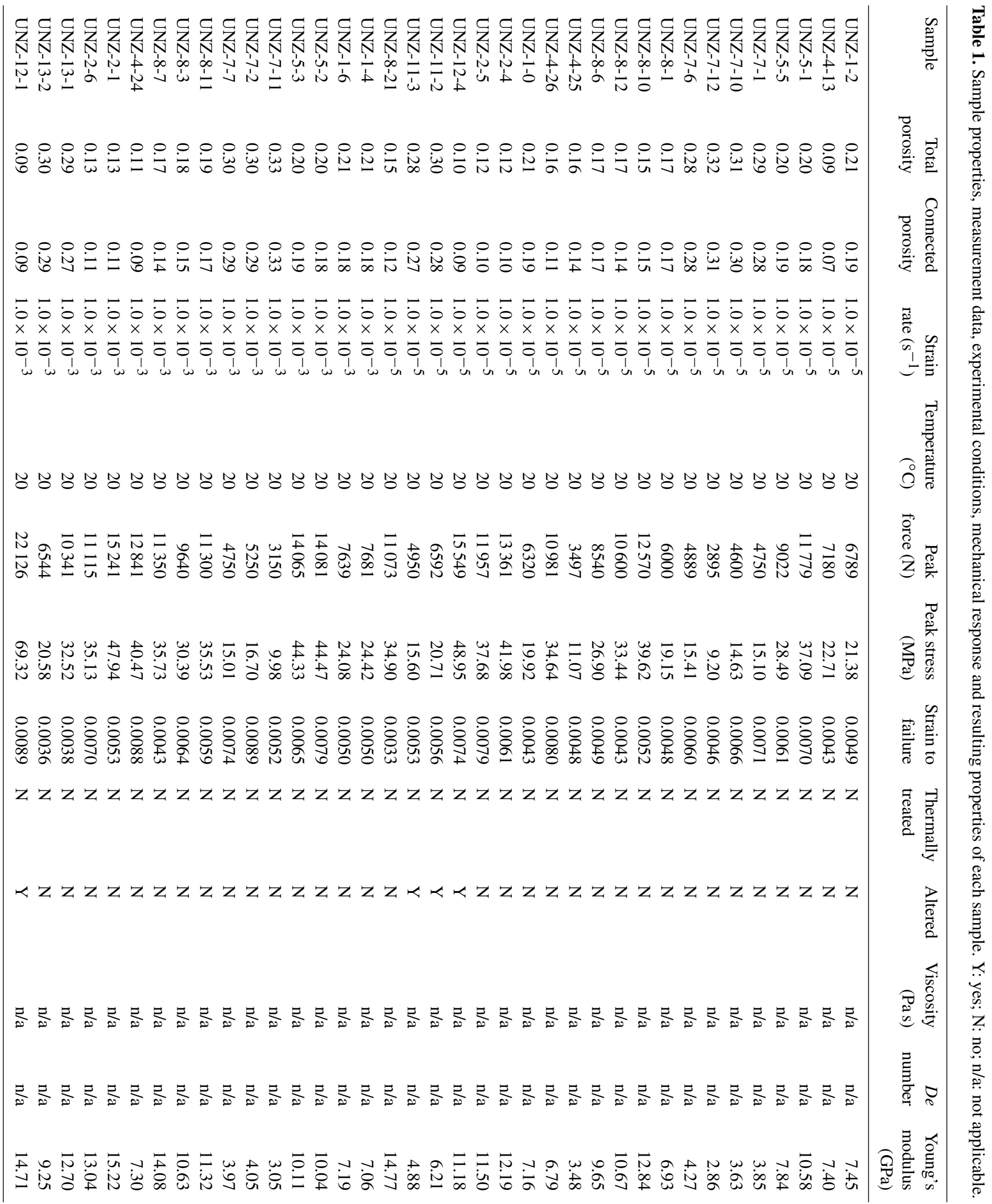




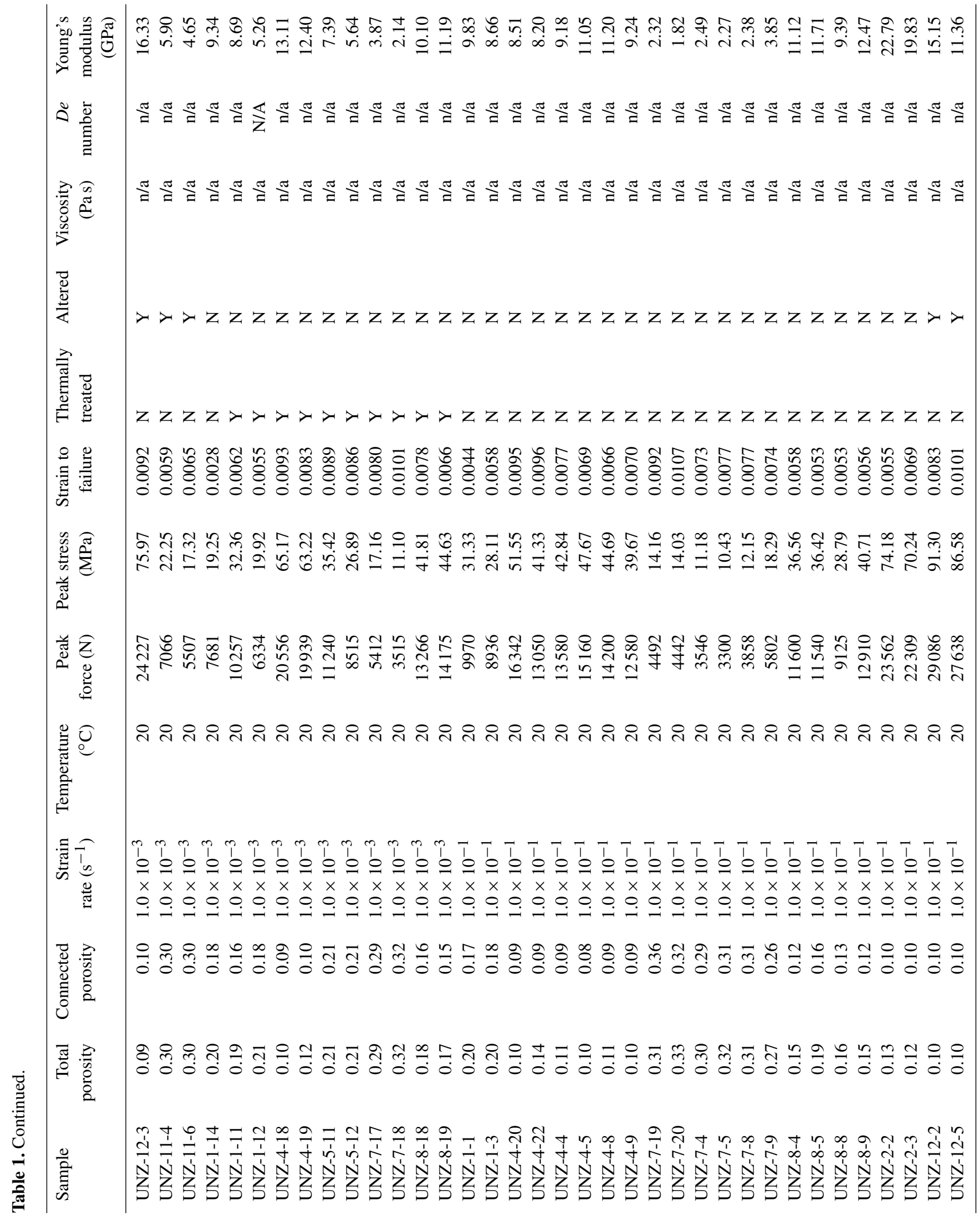




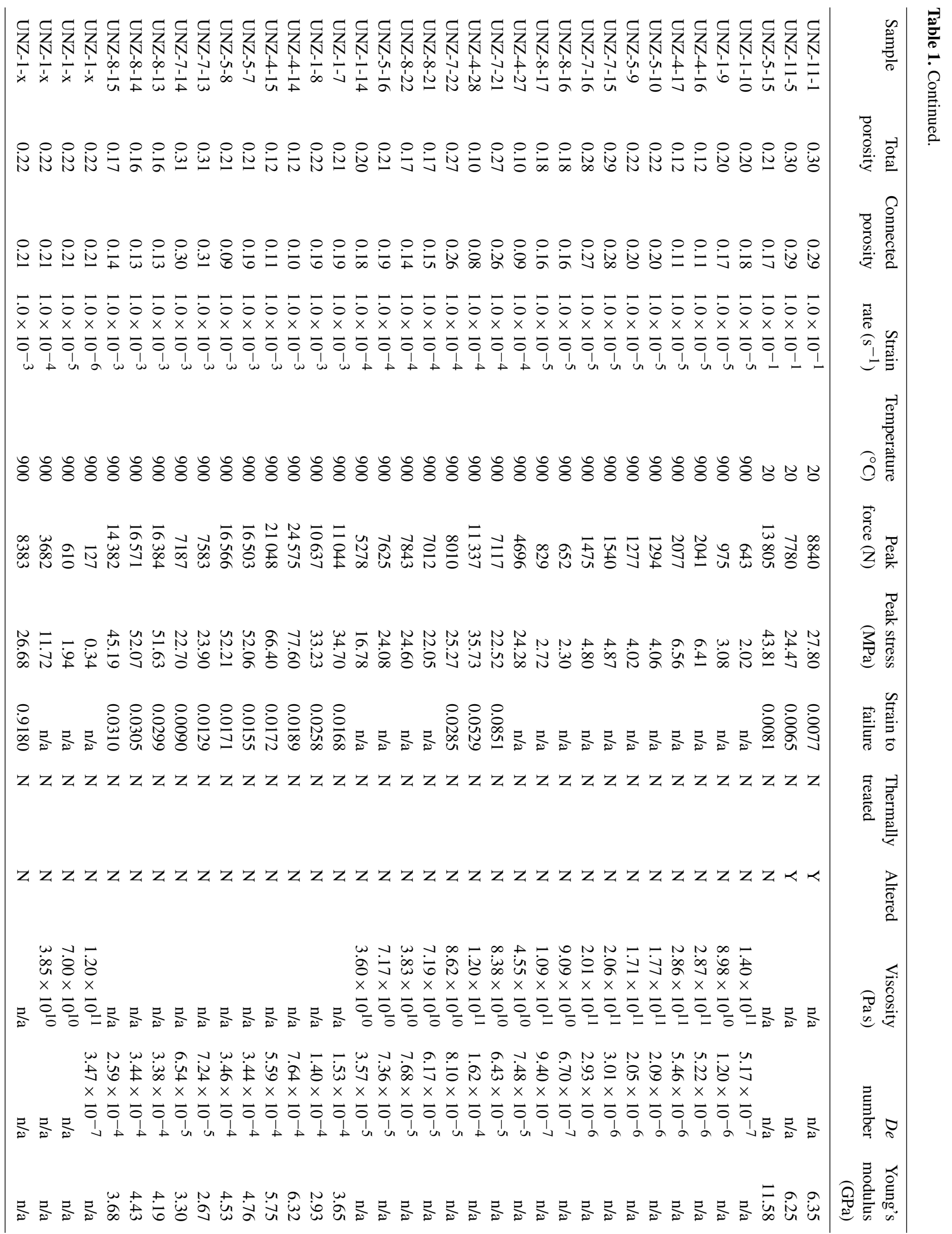




\subsection{Uniaxial compression experiments}

USC tests were carried out using a $50 \mathrm{kN} 5969$ Instron benchtop press and a $100 \mathrm{kN}$ Instron 8862 uniaxial press with a three-zone, split cylinder furnace using the parallel plate method in the Experimental Volcanology and Geothermal Research Laboratory at the University of Liverpool (Fig. 2). Experiments were carried out at both ambient temperature $\left(\sim 20^{\circ} \mathrm{C}\right)$ and high temperature $\left(900^{\circ} \mathrm{C}\right.$, using a heating rate of $\left.4^{\circ} \mathrm{C} \mathrm{min}^{-1}\right)$. Tests were conducted at constant strain rates of $10^{-1}, 10^{-3}$ or $10^{-5} \mathrm{~s}^{-1}$ (see Table 1 for the range of experimental conditions). The apparatus monitored the applied load and piston extension at $10-1000 \mathrm{~Hz}$ (depending on set experiment rate) and the Bluehill ${ }^{\circledR} 3$ software was used to compute data and calculate strain $(\varepsilon)$ and compressive stress from the input sample dimensions. Note that all mechanical data have been corrected for the compliance of the set-up at the relevant experimental temperature, quantified via Instron procedures that monitor length changes due to loading of the pistons in contact with one another. The end of each experiment was defined by either (1), in the case of viscous flow, when there was a constant stress recorded for a significant amount of time ( $>1 \mathrm{~h}$ ), or $(2)$, in the case of brittle behaviour, a stress drop exceeding $20 \%$ of the monitored peak stress achieved, highlighting that failure had occurred. Repeat experiments were performed on samples with a similar porosity (i.e. within 0.01 of the other sample tested) at various conditions to verify findings.

\subsubsection{High-temperature experiments}

Prepared cores were placed upright in between the pistons of the press; the furnace was closed around the sample, which was heated at $4{ }^{\circ} \mathrm{C} \min ^{-1}$ to $900 \pm 3{ }^{\circ} \mathrm{C}$ (sample temperature); a $\mathrm{K}$-type thermocouple was left in contact with the sample at all times and the temperatures of the top, middle and bottom zones of the furnace were monitored throughout the experiment. Following thermal equilibration for $1 \mathrm{~h}$ at target temperature, the piston was then brought into contact with the sample at low load $(<30 \mathrm{~N})$, and the temperature of the sample was read from the thermocouple. A stepped strain rate experiment (at $10^{-6}$ then $10^{-5}, 10^{-4}$ and $10^{-3} \mathrm{~s}^{-1}$ ) was first carried out to constrain the viscous-brittle transition of the material and inform subsequent testing at unique strain rates. Tests at unique strain rates were then carried out at $10^{-3}$, $10^{-4}$ and $10^{-5} \mathrm{~s}^{-1}$, after which, the samples were cooled to ambient temperature at $4{ }^{\circ} \mathrm{Cmin}^{-1}$. Note that from here on, samples deformed at high temperature will be defined as lavas, and those tested at room temperature as rocks.

\subsubsection{Ambient temperature experiments}

Ambient temperature experiments were carried out on all collected sample blocks. Prepared cores were placed upright between the pistons, where they underwent compressive tests at various strain rates until failure. The thermally stressed samples were tested at a strain rate of $10^{-3} \mathrm{~s}^{-1}$, whereas the remaining pristine specimens were axially loaded at strain rates of $10^{-1}, 10^{-3}$ or $10^{-5} \mathrm{~s}^{-1}$ until failure (see Table 1).

\subsubsection{Treatment of data}

The strain at failure for these samples was selected using a semi-automated MATLAB script which identified the strain value at peak stress. The static Young's modulus was computed for each experiment that exhibited a brittle response (e.g. after Heap et al., 2014a) by calculating the slope of the linear portion of the stress-strain curve via an automated script written in MATLAB and available at https://doi.org/10.5281/zenodo.1287237 (Coats, 2018). To ensure that only the linear portion was selected, points within $10 \%$ of the maximum slope were considered to define the Young's modulus for that sample (Fig. S6), minimising the potential contribution of mechanical data obtained during crack closure (during initial loading) and during strain hardening (beyond the onset of dilation).

For samples that demonstrated a viscous response, the apparent viscosity ( $\eta_{\mathrm{a}}$; in pascal seconds) was calculated using the equation of Gent (1960) developed for the parallelplate viscometric method, given the absence of slip along the sample-piston interfaces:

$\eta_{\mathrm{a}}=\frac{2 \pi F h^{4}}{3 V \dot{\varepsilon}\left(V+2 \pi h^{3}\right)}$,

where $F(\mathrm{~N})$ is the applied force on the sample, $h(\mathrm{~m})$ is the height of the sample, $V\left(\mathrm{~m}^{3}\right)$ is the initial volume of the sample, assumed constant, and $\dot{\varepsilon}\left(\mathrm{s}^{-1}\right)$ is the applied strain rate.

\section{Results}

\subsection{Sample characterisation}

\subsubsection{Mineralogy and geochemistry}

Normalised geochemical analysis for bulk and glass geochemistry, obtained by XRF and EPMA, respectively, are displayed in Table 2. Optical examination of the samples reveals that they consist of 20-50 vol \% phenocrysts and microphenocrysts of plagioclase $(>25 \mathrm{vol} \%)$, amphibole $(\sim$ $5 \mathrm{vol} \%)$, biotite $(\sim 2 \mathrm{vol} \%)$ and quartz $(\sim 2 \mathrm{vol} \%)$ (Fig. 3$)$, of which plagioclase and amphibole are the largest of the phenocrysts, and are generally larger than $3 \mathrm{~mm}$. These phenocrysts and microphenocrysts are set in a partially crystalline ( $\sim 50 \mathrm{vol} \%$ ) groundmass containing microlites of plagioclase, pyroxene, quartz, pargasite and Fe-Ti oxides in a peraluminous rhyolitic interstitial glass (as described in Cordonnier et al., 2009). Cristobalite is occasionally observed as pore infills (also recorded by Nakada and Motomura, 1999). The bulk chemistries of samples UNZ-11 and 

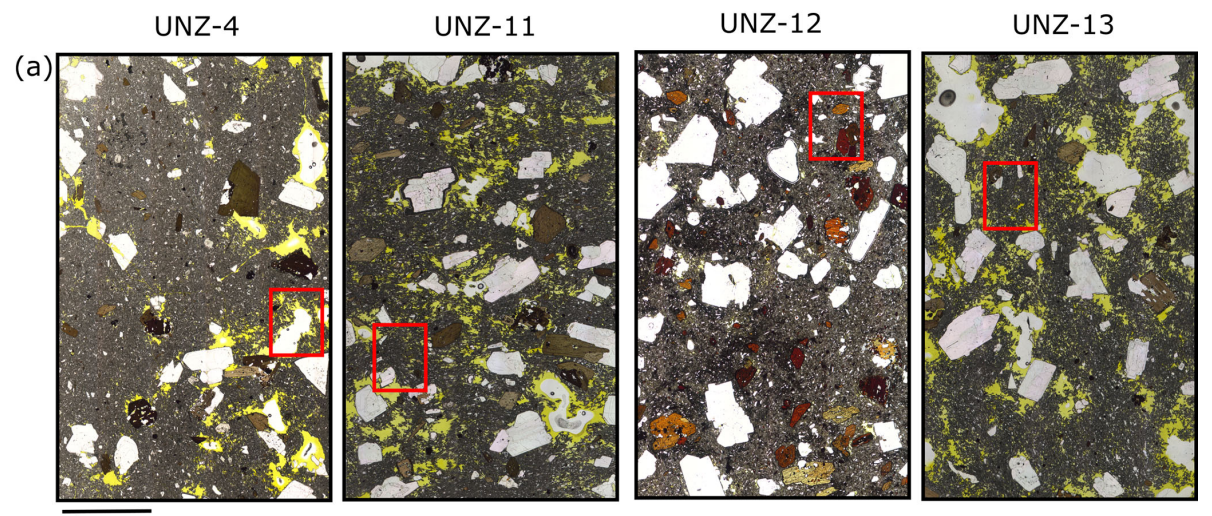

(b)
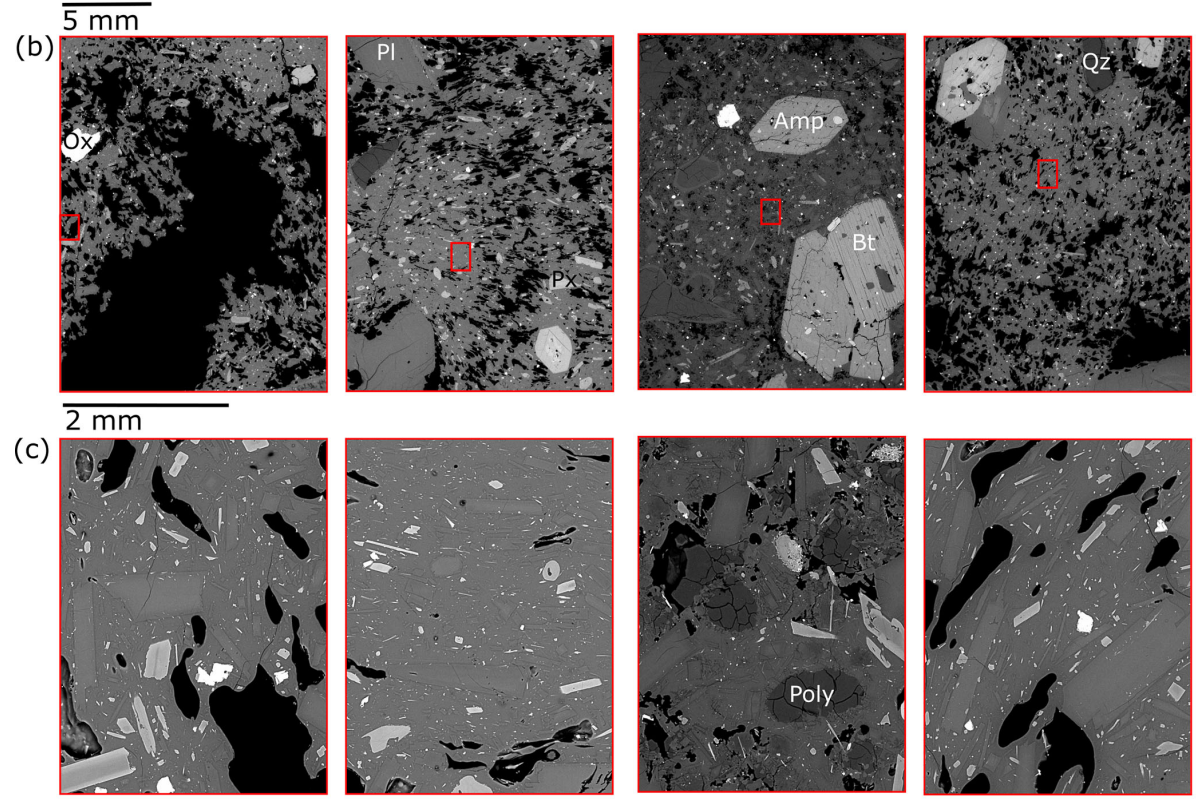

$\overline{100 \mu \mathrm{m}}$

Figure 3. Plane-polarised light (a) and backscattered electron images (b, c) of undeformed samples UNZ-4, UNZ-11, UNZ-12 and UNZ-13. Panel (b) is a zoom into the red box in panel (a), and panel (c) is a zoom of the red box in panel (b), displaying the groundmass textures. Amp: amphibole; Bt: biotite; Ox: oxides; Pl: plagioclase; Px: pyroxene; Qz: quartz; Poly: silica polymorph. Images are orientated so that the later applied principal stress, $\sigma_{1}$, is in the vertical direction. Note the scale that is below each set of images.

UNZ-12 (deemed visually altered) have slightly more (1.1$1.4 \mathrm{wt} \%) \mathrm{SiO}_{2}$ and slightly less $(0.55-0.63 \mathrm{wt} \%) \mathrm{CaO}$ than UNZ-4, whilst $\mathrm{K}_{2} \mathrm{O}$ and $\mathrm{Na}_{2} \mathrm{O}$ concentrations are almost identical.

\subsubsection{Rock porosities}

The total porosities of the samples determined by helium pycnometry measurements range from 0.10 to 0.32 (Table 3), a scatter which has previously been studied in an investigation of rock frictional properties (Hornby et al., 2015) and which is consistent with field measurements of Mt. Unzen 19911995 eruptive products (Kueppers et al., 2005). The pores of the denser products, notably UNZ-4 and UNZ-12, are fully connected, whereas the higher porosity blocks contain a portion (0.01-0.02) of isolated pores. The small standard devia- tion for the connected, isolated and thus total porosity of the rocks ensures the comparability of mechanical data obtained on samples with similar porosities during repeats.

\subsubsection{Microstructures}

Microstructural examination can be used to assess any preexisting anisotropy or fabrics in the lavas. Photomicrographs along with SEM images, of a selected group of samples (UNZ-4, UNZ-11, UNZ-12, UNZ-13), can be seen in Fig. 3. These samples are shown due to their contrasting nature, covering the span of textures studied here: UNZ-11 and UNZ12 are visually altered samples, UNZ-13 has a different pore anisotropy than UNZ-11 and UNZ-4 is a typical product of the block-and-ash flow and is representative of the remaining samples tested. The images in Fig. 3 show the original ma- 
Table 2. Normalised chemical composition of bulk rocks obtained by XRF analysis and interstitial glass obtained by EPMA. UNZ-4 was selected as it is representative of fresh lavas tested in this study; in contrast, UNZ-11 and UNZ-12 were deemed to display a certain degree of alteration. Original totals were 99.97, 100.39, 100.09 and 99.95 for UNZ-4, UNZ-12, UNZ-11 and UNZ-4 glass, respectively, before normalisation for direct comparison. The standard deviation of the UNZ-4 glass was taken from two measurements.

\begin{tabular}{lrrr|rr}
\hline & \multicolumn{3}{c|}{ XRF } & \multicolumn{2}{c}{ Microprobe } \\
\cline { 2 - 6 } & UNZ-4 & UNZ-11 & UNZ-12 & $\begin{array}{r}\text { UNZ-4 } \\
\text { glass }\end{array}$ & $\begin{array}{r}\text { Standard } \\
\text { deviation }\end{array}$ \\
\hline $\mathrm{SiO}_{2}$ & 64.07 & 65.2 & 65.48 & 79.20 & 0.20 \\
$\mathrm{TiO}_{2}$ & 0.67 & 0.66 & 0.61 & 0.40 & 0.01 \\
$\mathrm{Al}_{2} \mathrm{O}_{3}$ & 16.34 & 15.98 & 16.39 & 11.13 & 0.02 \\
$\mathrm{Fe}_{2} \mathrm{O}_{3}$ & 4.84 & 4.67 & 4.35 & - & - \\
$\mathrm{FeO}$ & - & - & - & 0.92 & 0.01 \\
$\mathrm{MnO}$ & 0.10 & 0.10 & 0.09 & 0.01 & 0.01 \\
$\mathrm{MgO}$ & 2.57 & 2.37 & 2.02 & 0.07 & 0.02 \\
$\mathrm{CaO}$ & 5.18 & 4.55 & 4.63 & 0.56 & 0.02 \\
$\mathrm{Na} 2 \mathrm{O}$ & 3.61 & 3.56 & 3.69 & 2.83 & 0.09 \\
$\mathrm{~K}_{2} \mathrm{O}$ & 2.31 & 2.55 & 2.46 & 4.87 & 0.07 \\
$\mathrm{P}_{2} \mathrm{O}_{5}$ & 0.17 & 0.12 & 0.15 & - & - \\
$\mathrm{LOI}$ & 0.14 & 0.23 & 0.14 & - & - \\
$\mathrm{Total}$ & 100 & 100 & 100 & 100 & 0 \\
\hline
\end{tabular}

terials, orientated so that the direction of principal stress, $\sigma_{1}$, applied to the cores prepared of each rock would be in the vertical direction.

It is evident from Fig. 3 that the pores in the Mt. Unzen dome rock samples are preferentially elongate. In some cases, the elongation has a preferred orientation (e.g. UNZ11, UNZ-13), while in others it is unsystematic (e.g. UNZ4, UNZ-12). In UNZ-11 vesicles, and microlites, appear to bottleneck around phenocrysts in a horizontal direction (i.e. perpendicular to $\sigma_{1}$ imposed in the experiments), whereas in UNZ-13 their alignment is vertical (i.e. parallel to $\sigma_{1}$ ), indicating a sense of shear in those directions. UNZ-4, UNZ11 and UNZ-13 have a significant number of larger pores ( $>1 \mathrm{~mm}$ ) when compared to UNZ-12, and across the shown sample set these larger pores appear as pressure shadows around the phenocrysts (e.g. see McKenzie and Holness, 2000). Fractures are only clearly visible in UNZ-4; this is most likely due to higher abundance and larger fracture widths in this sample, allowing them to be visible in both thin section and BSE images. The fractures appear to connect pores via the tip of their major axis.

The groundmass of UNZ-12 contains a scaly textured silica polymorph that appears to have filled vesicles. Common silica polymorphs seen at Mt. Unzen, and other domes across the world (e.g. Mt. St. Helens; Voight et al., 1981), are cristobalite precipitates, formed from hydrothermal activity (Nakada and Motomura, 1999; Voight et al., 1981, 1999). This silica deposit has filled a considerable number
( $\sim 50 \mathrm{vol} \%$ ) of the vesicles in UNZ-12, reducing its porosity (Fig. 3c). Although the polymorph is a sign of alteration, in the highest magnification BSE image, some glass appears to have remained vitreous between silica polymorph areas. In UNZ-11, neither the phenocrysts nor the groundmass show evidence of alteration (Fig. 3b, c).

In UNZ-12 the phenocrysts are visually more abundant ( $>20 \mathrm{vol} \%$ ) than in the other specimens (Fig. 3). Nakada and Motomura (1999) observed that groundmass crystallinity increased from 33 to $50 \mathrm{vol} \%$ with decreasing effusion rate, as was the case towards the end of the eruption (Nakada et al., 1995), consistent with $\sim 55 \mathrm{vol} \%$ groundmass crystallinity in the 1994-1995 spine (Wallace et al., 2017). These observations are also consistent with the crystal fractions measured in UNZ-12, collected from the near-vent area.

\subsubsection{The influence of thermal stressing}

The skeletal volume, mass and dimensions of each core were measured before and after thermal stressing in order to assess changes in porosity that may accompany microstructural adjustment in the process. Results showed that over the 12 cores subjected to thermal stressing, the change in connected porosity was less than 0.001 , which is within the resolution of the method. Thus, it may be said that thermal stressing did not markedly create pores or connect isolated vesicles. It did however cause a slight decrease in the values of Young's modulus.

\subsection{Uniaxial compressive experiments}

\subsubsection{Mechanical response of Mt. Unzen dome rocks}

USC tests were conducted on 66 cores at ambient temperature. For those samples which had a brittle response to uniaxial compression, the failure process can be segregated into four stages (e.g. Hoek and Bieniawski, 1965; Brace et al., 1966; Scholz, 1968; Heap et al., 2014a). An initial buildup of stress has been attributed to the closure of microcracks perpendicular to $\sigma_{1}$; this is the initial convex segment on the stress-strain curve (e.g. Fig. 4a, b). The second linear increase in stress and strain has been attributed to dominantly elastic (recoverable) deformation. Strain hardening marks the onset of microfracturing that imparts permanent non-recoverable damage, causing deviation from the linear elastic regime during loading (seen as the concave section of the stress-strain curve; Fig. 4a, b). Finally, a peak in stress is reached, followed by an abrupt stress drop; this is associated with throughgoing fracture propagation and coalescence before macroscopic failure is reached. This behaviour is seen in the stress-strain curves (Figs. 4a, b, S3, S4) of all samples deformed in the brittle regime, be it at ambient temperature (for all strain rates) or at high temperatures (for faster strain rates; see Sect. 3.2.2). 
Table 3. Average total, connected and isolated porosities for each sample block used. A larger number of cores were measured to calculate the average porosities than those used in strength tests. Note the values are presented to two decimal places but were calculated with four decimal places.

\begin{tabular}{lrrrrrrr}
\hline $\begin{array}{l}\text { Sample } \\
\text { block } \\
\text { name }\end{array}$ & $\begin{array}{r}\text { Average } \\
\text { total } \\
\text { porosity }\end{array}$ & $\begin{array}{r}\text { Standard } \\
\text { deviation }\end{array}$ & $\begin{array}{r}\text { Average } \\
\text { connected } \\
\text { porosity }\end{array}$ & $\begin{array}{r}\text { Standard } \\
\text { deviation }\end{array}$ & $\begin{array}{r}\text { Average } \\
\text { isolated } \\
\text { porosity }\end{array}$ & $\begin{array}{r}\text { Standard } \\
\text { deviation }\end{array}$ & $\begin{array}{r}\text { No. } \\
\text { samples }\end{array}$ \\
\hline UNZ-1 & 0.21 & 0.011 & 0.18 & 0.012 & 0.02 & 0.002 & 17 \\
UNZ-2 & 0.13 & 0.016 & 0.11 & 0.018 & 0.02 & 0.003 & 7 \\
UNZ-4 & 0.12 & 0.016 & 0.12 & 0.021 & 0.00 & 0.016 & 30 \\
UNZ-5 & 0.21 & 0.006 & 0.19 & 0.009 & 0.02 & 0.006 & 18 \\
UNZ-7 & 0.30 & 0.024 & 0.29 & 0.025 & 0.01 & 0.002 & 23 \\
UNZ-8 & 0.16 & 0.016 & 0.14 & 0.016 & 0.02 & 0.003 & 24 \\
UNZ-11 & 0.30 & 0.009 & 0.29 & 0.011 & 0.01 & 0.004 & 8 \\
UNZ-12 & 0.10 & 0.025 & 0.09 & 0.026 & 0.00 & 0.002 & 7 \\
UNZ-13 & 0.32 & 0.005 & 0.30 & 0.004 & 0.01 & 0.004 & 6 \\
\hline
\end{tabular}

The strength of the rocks was observed to decrease with porosity (Fig. 5a). The range of strength of dense rocks is higher than porous rocks. We observe that rock strength increases with applied strain rates at all porosities, although this effect is more pronounced for dense rocks. The data suggest that the rocks deemed altered (UNZ-11, UNZ-12) are not weaker but indeed stronger than pristine rocks with equivalent porosities (see circled data points in Fig. 5a).

The overlap among the datasets obtained for thermally stressed and as-collected samples suggests that thermal stressing did not impart significant damage or mineralogical changes (if any) to modify the strength of these rocks (Fig. 5). Yet, a closer look at the mechanical data suggests that the initial convex increase in stress with strain is more pronounced for the thermally stressed samples than for their pristine equivalent (Fig. 4c), indicating that the thermally stressed samples have more cracks to close than their untreated equivalents. It is therefore likely that thermal stressing has caused the creation or opening of microfractures, dislocating the rocks slightly in the process but not enough to cause a notable increase in porosity or decrease in strength

\subsubsection{Rheological response of Mt. Unzen dome lavas}

The mechanical data of lavas show a wider range of behaviour than those obtained on rocks at ambient temperature (Fig. 4a, b). At slower strain rates of $10^{-4}$ and $10^{-5} \mathrm{~s}^{-1}$, samples may provide a viscous response. Initially, the stressstrain curves exhibit only a mildly convex stress build-up, but then deformation is dominated by a stress relaxation phase which results in a levelling of the stress to a steady value as strain amasses (orange and red lines, Fig. 4a, b). This represents the viscous flow of the suspension and, as such, its apparent viscosity can be calculated from the mechanical data. At faster strain rates $>10^{-3} \mathrm{~s}^{-1}$, samples may respond brittlely. In this regime, as at ambient (room) temperature, stress accumulation may eventually lead to failure and a significant stress drop (e.g. maroon line, Fig. 4b). The behaviour that links the viscous and brittle response is termed transitional. If the plateau in the stress-strain curves is marked with minor stress drops, this signals a transitional response to deformation that is dominantly viscous. Where there is a major drop in the stress-strain curve that takes place over an extended period of strain, we termed this response brittle-dominated transitional (maroon line, Fig. 4a). This interpretation of mechanical data can also be confirmed by analysing the microstructure of deformed samples (Fig. 6). Samples with pervasive macro-fractures that propagate through both groundmass and, to a lesser extent, the phenocrysts have likely undergone fully brittle deformation. Likewise, samples with a response classified as brittle-dominated transitional also have pervasive macro-fractures; however the phenocrysts are only slightly displaced along their cleavage planes, rather than shattered. Samples that have had a viscous-dominated transitional response to strain display microfractures in both the groundmass and phenocrysts, and those that have had a viscous response show little to no microfracturing. A viscous response may also lead to elongation of porosity parallel to the sense of shear.

The evolution of apparent viscosity is strain rate dependent as shown by the stepped strain rate experiment (Fig. 7). An increase in the strain rate resulted in an order of magnitude decrease in viscosity- a thixotropy of similar magnitude to that described for highly crystalline magmas in Lavallée et al. (2007). In this experiment, deformation at low strain rates of $10^{-6}, 10^{-5}$ and $10^{-4} \mathrm{~s}^{-1}$ is marked by a nonlinear increase in apparent viscosity (upon stress relaxation) and plateauing to a constant value for each strain rate step; this value decreased with increase in the applied strain rate (Fig. 7). Deformation was pervasive (i.e. ductile), which, being above $T_{\mathrm{g}}$, suggests that it may have dominantly occurred via a viscous response. At $10^{-3} \mathrm{~s}^{-1}$, however, the apparent viscosity plummeted as the sample underwent failure along a 

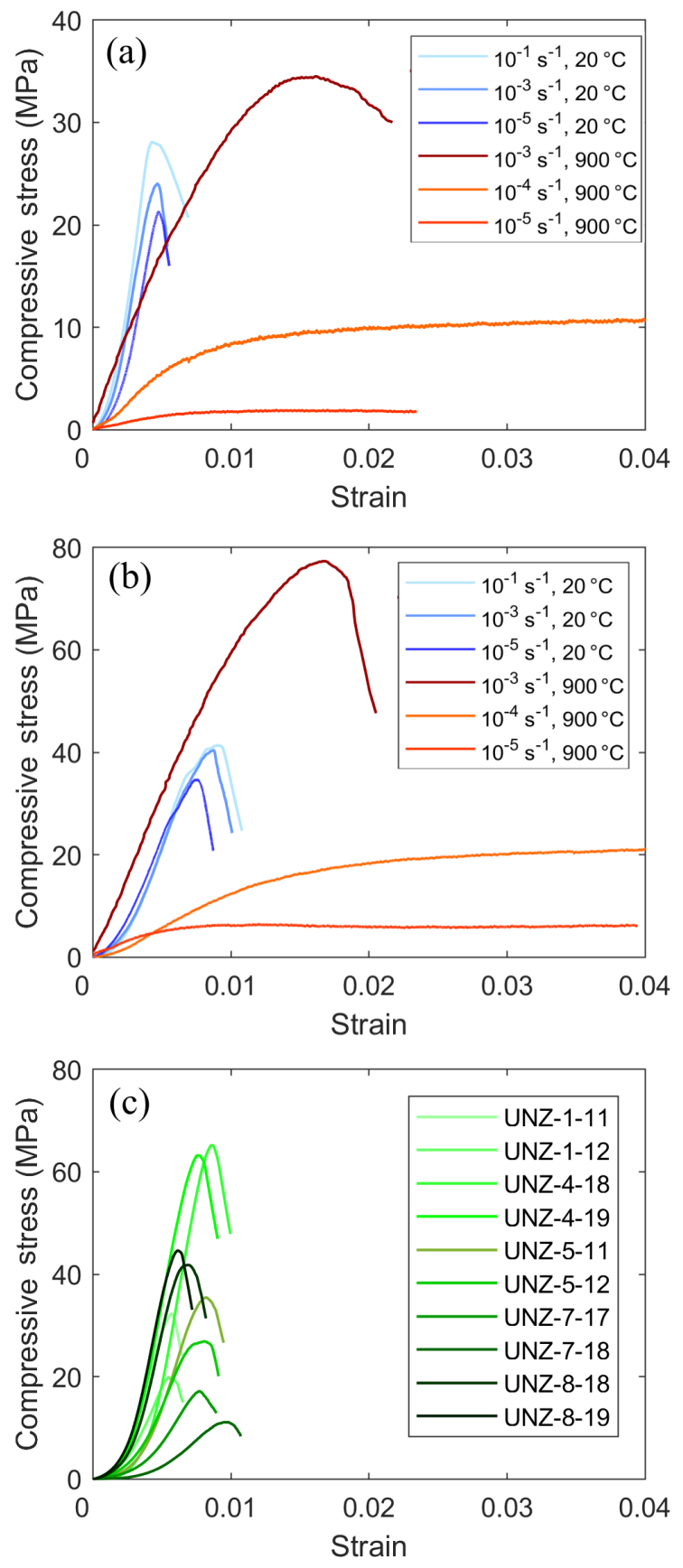

Figure 4. Examples of compressive stress-strain curves for (a) high porosity $(0.21) \mathrm{UNZ}-1$, (b) low porosity $(0.12) \mathrm{UNZ}-4$, at a range of rates and temperatures, and (c) thermally stressed samples, all performed at a strain rate of $10^{-3} \mathrm{~s}^{-1}$. Mechanical data for hightemperature experiments are shown in shades of red, low temperature experiments in shades of blue and thermally stressed experiments in shades of green. At high temperature, faster strain rates cause the sample to break, whereas at slower strain rates the sample flows. Brittle high-temperature experiments fail at considerably higher peak stresses than those performed at ambient temperatures. In the brittle regime, samples deformed at faster rates failed at higher stresses. Note that there is a difference in the $y$ scale among panels (a) and (b) and (c). localised fault, evidencing a transition into the brittle regime (Fig. 7b).

At strain rates of $10^{-3} \mathrm{~s}^{-1}$ the sample suite tested reached peak stresses of $\sim 20-80 \mathrm{MPa}$ (Fig. 8a) and strength decreased inversely with porosity. Here the samples responded with a brittle and brittle-dominated transitional response to strain. The mechanical responses of samples tested at high temperature were more repeatable than those carried out at ambient temperature: the strength of samples (within a family with $\sim 0.01$ porosity range) was within $\sim 2 \%$ of each other at low porosities $(<0.20)$ and within $\sim 5 \%$ of each other at high porosities $(>0.20)$, whereas at ambient temperatures a variation of $\sim 60 \%$ is observed in the lower porosity regime (Table 1).

When a strain rate of $10^{-4} \mathrm{~s}^{-1}$ was applied some of the samples reached peak stresses between $\sim 10$ and $35 \mathrm{MPa}$ (Fig. 7b), before relaxing the stress through substantial strain. Here, the lavas display a viscous and viscous-dominated transitional response to strain. In some samples, an initially viscous response transitioned to fracturing after a certain amount of strain, leading to macroscopic failure. Samples that did not fracture continued to flow viscously with increasing strain, with a component of strain hardening, similar to that seen by Kendrick et al. (2013b). Samples that were subjected to a strain rate of $10^{-5} \mathrm{~s}^{-1}$ had a fully viscous response over the strain rates tested (Fig. 8c). Remarkably, the peak stresses of samples tested at $10^{-4}$ and $10^{-5} \mathrm{~s}^{-1}$ were seemingly independent of porosity (Fig. 8d).

The apparent viscosities calculated from the responses at $10^{-5}$ and $10^{-4} \mathrm{~s}^{-1}$ show an initial increase (due to relaxation in the first $0.7 \%$ of strain) and levelling to within a narrow range (see Fig. 9a, b). For a given strain rate, we note a small range of apparent viscosities, but importantly, no systematic change in viscosity as a function of sample porosity (within the range tested, Fig. 9c).

These results indicate that the transition in deformation mode from macroscopically ductile to brittle behaviour is straddled by our experiments in the range from $10^{-5}$ to $10^{-3} \mathrm{~s}^{-1}$.

\section{Interpretation of dome rock mechanics}

\subsection{Mechanical responses of rocks and lavas in the brittle and brittle-dominated transitional regime}

The experimental findings presented here suggest that the mechanical response of lavas and rocks is similar, but important differences remain. Experiments carried out on rocks at ambient temperature (all strain rates), and on some lavas at strain rates of $10^{-3} \mathrm{~s}^{-1}$, resulted in brittle behaviour. However, there are significant differences in the mechanical response between the two (Fig. 4). (1) We noted a shorter convex portion at the onset of the stress-strain curve of tests at high temperature (Fig. S3), which we attribute to a narrow- 

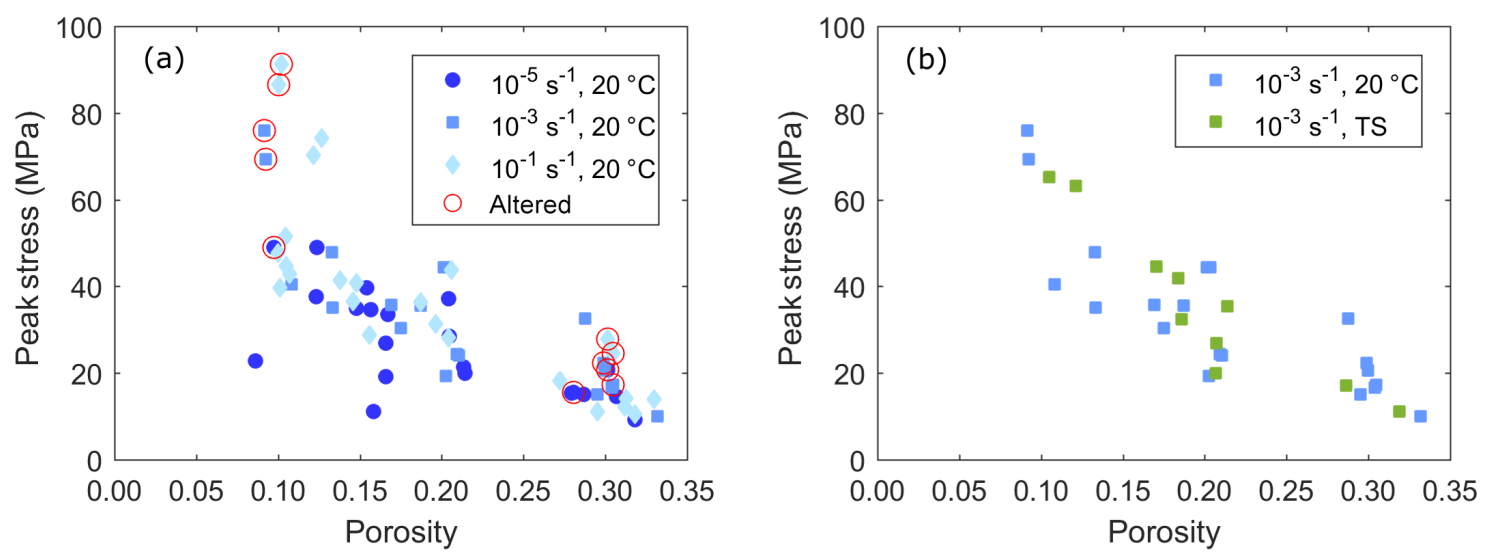

Figure 5. (a) The strength (peak stress) of samples tested at ambient temperatures at varying strain rates, highlighting the apparent strengthening of materials deformed at a faster rate. Red rings circle the samples that are visibly altered. (b) A comparison of samples that were thermally stressed and those that were not, both tested at ambient temperatures and strain rates of $10^{-3} \mathrm{~s}^{-1}$, demonstrating that there is no change in strength as a function of porosity due to thermal stressing.

ing of pre-existing cracks at high temperature (due to thermal expansion of the materials with heating; e.g. Fig. S5), resulting in a smaller extent of crack closure during initial loading. (2) Most high-temperature samples have a shallower linear portion of stress-strain build-up, which we hypothesise may reflect a contribution of viscous deformation upon loading, leading to a brittle-dominated transitional classification. (3) We observed a less angular concave downward portion of the stress-strain curve, which we attribute to more pervasive deformation (as seen by longer strain to failure; Fig. 10) and microfracturing leading to failure. The exception to these findings is in the highest porosity sample, UNZ7 , in which there appears to be no significant change in shape between high and ambient temperature experiments (see Figs. S3, S4). This sample was classified in the fully brittle regime. It remains that at higher temperature, lavas are stronger (by 10-40 MPa; Figs. 4-9) than their rock equivalents at ambient temperature. Before delving into their differences (Sect. 4.1.4), we will first interpret the results on the strength (Sect. 4.1.2) and Young's modulus (Sect. 4.1.3) of porous rocks at ambient temperature.

\subsubsection{The effect of porosity on material strength}

From the results of the uniaxial compressive experiments it is evident that porosity is a major control on the strength of dome materials. Previous studies on volcanic rocks (AlHarthi et al., 1999; Heap et al., 2014a, b, 2016b; Schaefer et al., 2015) have found a similar correlation in which, to a first order, strength is inversely proportional to the porosity of the rock.

Here, the strength of samples with higher porosities displays less scatter than that of samples with lower porosities (Fig. 10a). Microstructural examination of the samples (Fig. 3) reveals the porosity of the porous speci- mens to be dominated by vesicles, whereas the porosity of the denser samples is dominated by microfractures, which may define a change in the microstructural control on the strength and failure of low- and high-porosity samples. In these lower-porosity specimens, the non-systematic orientation of microfractures could be responsible for the large scatter in strength. The USC was calculated for the samples for both the pore-emanating crack model of Sammis and Ashby (1986) (Eq. 3) and the sliding wing crack model of Ashby and Sammis (1990) (Eq. 4). For the former, the USC was calculated with varying values of $\frac{K_{\mathrm{IC}}}{\sqrt{\pi r}}$ from 5 to $25 \mathrm{MPa}$ (Fig. 11). For the latter, approximate values for $\mu, \frac{K_{\mathrm{IC}}}{\sqrt{\pi c}}$ and $D_{0}$ were taken from Table 3 in Paterson and Wong (2005) as $0.51,20-30 \mathrm{MPa}$ and $0.3-44$, respectively. This gave a range of estimated strength between 54 and $90 \mathrm{MPa}$ (Fig. 11). At higher porosities, $>0.25$, the poreemanating crack model with $\frac{K_{\mathrm{IC}}}{\sqrt{\pi r}}=5-10 \mathrm{MPa}$ seems to fit the data well, whereas for most rocks with porosities of $0.12-0.2 \frac{K_{\mathrm{IC}}}{\sqrt{\pi r}}, 10-15 \mathrm{MPa}$ is a better fit. This could be explained by a decrease in the pore radius at these porosities, leading to higher values of $\frac{K_{\mathrm{IC}}}{\sqrt{\pi r}}$, though, as the samples are heterogeneous and pore radius variability is high, we cannot observe this (Fig. 3). For the densest rocks in the study $(\sim 0.08-0.12)$, the UCS data would suggest yet a higher $\frac{K_{\mathrm{IC}}}{\sqrt{\pi r}}$ of 20-25 MPa. The pore-emanating crack model could explain this switch in behaviour if there was a fundamental change in pore radius. However, the switch could also be explained by a transition in failure mechanism from poreemanating cracks to wing cracks, meaning the wing-crack model would be more applicable. Alternatively, it may be a complex combination of the two. Although the solutions to the sliding wing-crack model are non-unique, as there are few experimentally constrained parameters, when combined with information gained from the pore structures (Fig. 3), 

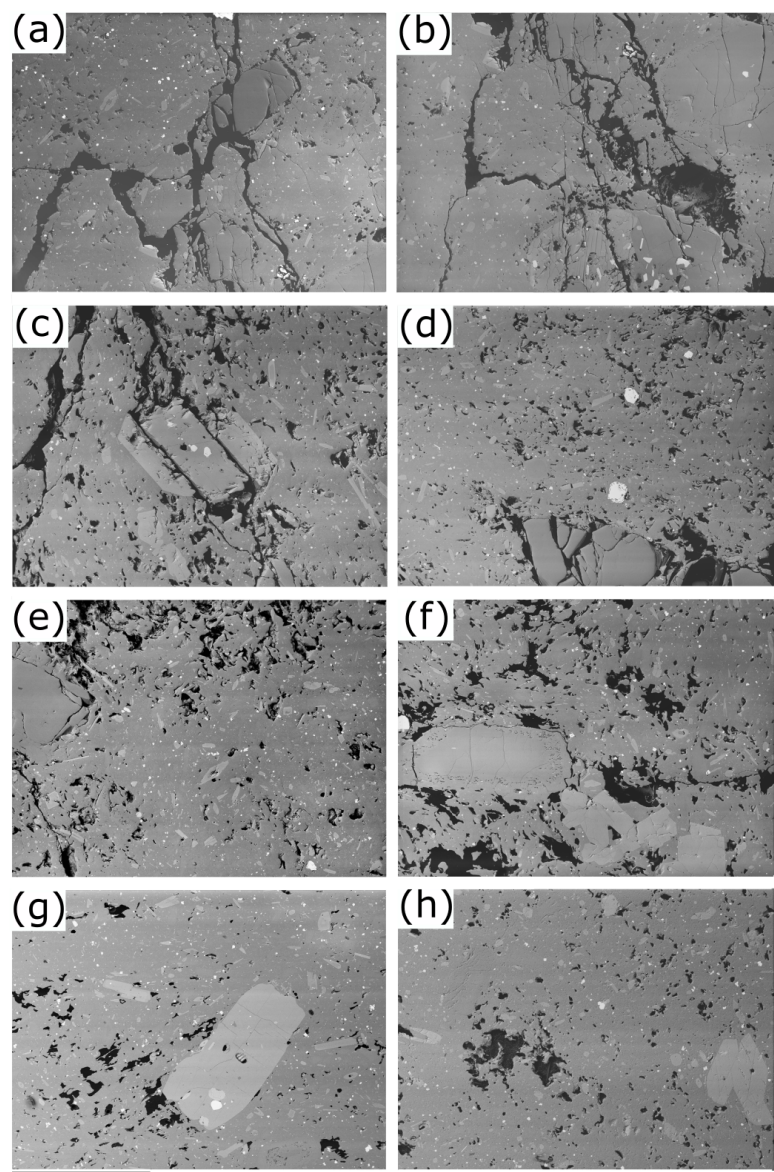

$1 \mathrm{~mm}$

Figure 6. Backscattered electron images of polished stubs for samples after strain (a-f) and before strain (g, h). Panels (a) and (b) show sample UNZ-4-14 after experiencing brittle deformation at a strain rate of $10^{-3} \mathrm{~s}^{-1}$; macroscopic cracks $(>100 \mu \mathrm{m}$ in width) propagate through both the groundmass and phenocrysts. Panel (c) shows sample UNZ-8-14 after experiencing brittle-dominated transitional behaviour at a strain rate of $10^{-3} \mathrm{~s}^{-1}$; pervasive macroscopic fractures ( $>100 \mu \mathrm{m}$ in width) connect porosity and displace phenocrysts along their planes of weakness. Panels (d) and (e) are representative images of UNZ-8-21, which underwent viscousdominated transitional behaviour when strained at $10^{-4} \mathrm{~s}^{-1}$; small ( $<200 \mu \mathrm{m}$ in width) microfractures can be seen in the groundmass glass; phenocrysts are pervasively fractured but show no sign of displacement. Panel (f) is an image of sample UNZ-8-16 after experiencing viscous deformation at a strain rate of $10^{-5} \mathrm{~s}^{-1}$; pores are aligned parallel to the direction of shear around phenocrysts with minor fractures $<100 \mu \mathrm{m}$ in width. Panels (g) and (h) show UNZ-4 and UNZ-8, respectively, prior to deformation, with a few hairline fractures visible in the phenocrysts and few to no fractures in the smaller crystals or the groundmass glass.

the results of the modelling presented (Fig. 11) give us insight into the dominant micromechanical failure mode of our samples. It is likely that the complex pore structures of these lavas, generated by a combination of vesiculation, de-

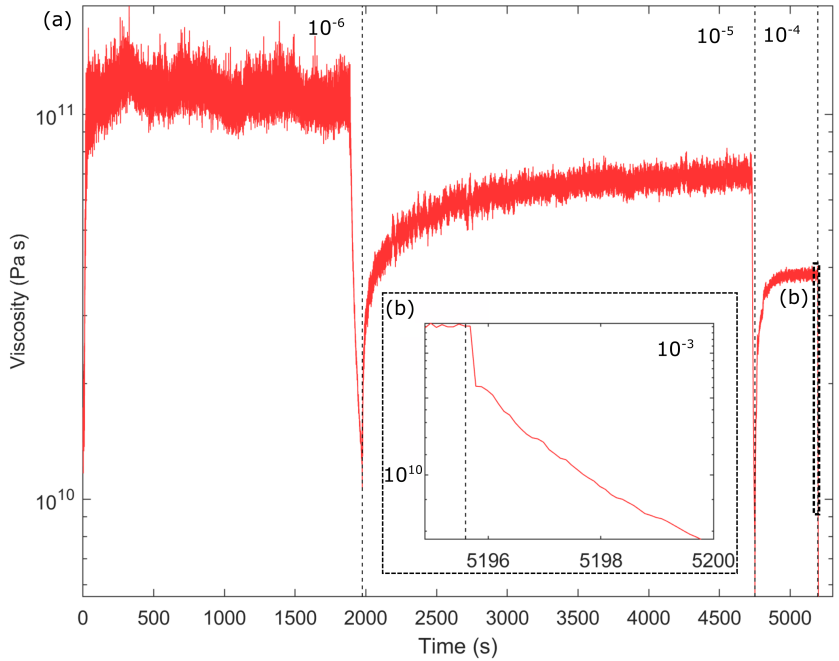

Figure 7. (a) Apparent viscosity evolution of UNZ-1 (porosity: $0.22)$ at $900^{\circ} \mathrm{C}$ during a stepped strain rate experiment $\left(10^{-6}\right.$, $10^{-5}, 10^{-4}, 10^{-3} \mathrm{~s}^{-1}$ ); each step is separated by dashed lines. The insert (b) zooms in on the apparent viscosity decrease that accompanies sample failure at $10^{-3} \mathrm{~s}^{-1}$. The decrease in viscosity at each increasing strain rate increment highlights the shear thinning behaviour of these lavas.

formation and cooling-driven contraction, require an as-ofyet undefined combination of the two models. The weighting towards one or the other, however, indicates that for the higher-porosity specimens the behaviour of failure could be described using the pore-emanating crack model of Sammis and Ashby (1986), whereas in the lower-porosity samples deformed in uniaxial compression, the main failure mechanism is explained by the sliding wing-crack model of Ashby and Sammis (1990).

This transition in the preference of fracture nucleation site from pore to crack is likely to be gradual and dependent on the pore network architecture of a suite of samples; in these Mt. Unzen samples it is found at a porosity of $\sim 0.2$. Other studies have also alluded to such a transition when studying permeability, finding a transition from a crack-dominated to pore-connectivity-dominated regime of fluid flow at values of $\sim 0.14$ (Farquharson et al., 2015), 0.155 (Heap et al., 2015), 0.105-0.31 (Kushnir et al., 2016), 0.15 (Eggertsson et al., 2018) and 0.11-0.18 (Lamur et al., 2017).

Samples UNZ-11 (porosity: 0.30) and UNZ-13 (porosity: 0.32 ) both have elongated vesicles. The cores were cut so that the vesicles were either perpendicular or parallel to the applied principal stress, $\sigma_{1}$, for UNZ-11 and UNZ-13, respectively (Fig. 3). The porosities of the two rocks are comparable, and there is no great difference in strength, indicating that pore orientation may not have a significant influence on strength within dome rocks. However, we do note that UNZ11 undergoes a higher strain to failure (Fig. 10b) and thus lower Young's modulus (Fig. 10c) than UNZ-13, indicating 

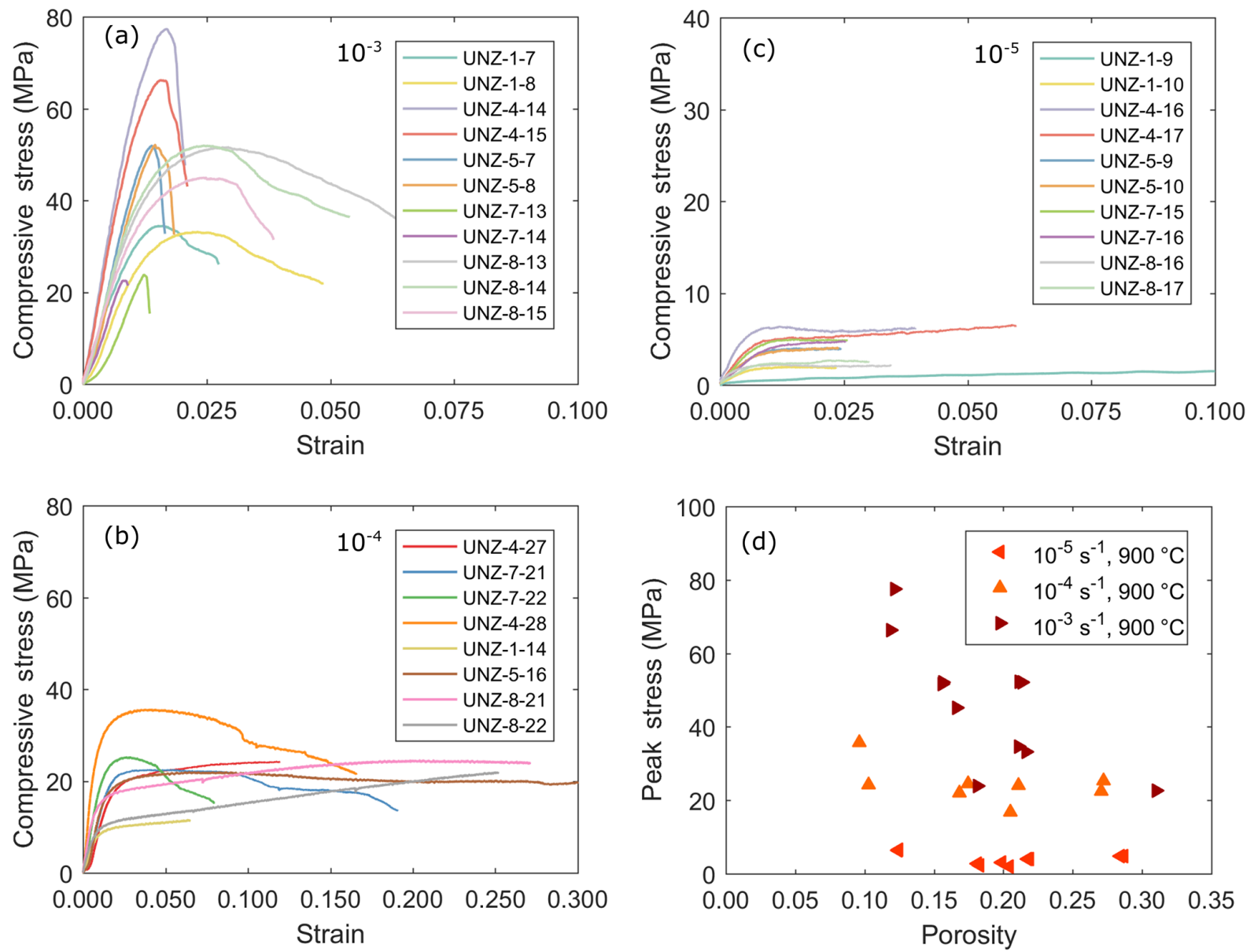

Figure 8. High-temperature uniaxial experiment results, including stress-strain curves for samples tested at strain rates of (a) $10^{-3}$, (b) $10^{-4}$ and (c) $10^{-5} \mathrm{~s}^{-1}$, demonstrating the shift from viscous flow at a low rate to increasingly brittle deformation at a faster rate. (d) The peak stresses achieved during each experiment carried out at $900^{\circ} \mathrm{C}$ further highlight this observation and show the porosity dependence of strength in the brittle regime.

that it is less stiff. Sample UNZ-2 (porosity: 0.13), however, does have a remarkably larger USC ( $\sim 20 \mathrm{MPa})$ and Young's modulus $(\sim 5-10 \mathrm{GPa})$ than samples of similar porosity. This may be due to the high number of spherical isolated pores (Table 3, Fig. S2) which act as rigid bodies. However, it cannot be explicitly stated that pore anisotropy did not play a role in this and thus it is possible that the orientation of a pore may have a dominant effect on the strength and stiffness of the dome rock (Bubeck et al., 2017; Griffiths et al., 2017). Thus, future studies on rock strength may benefit from an indepth study of rock strength as a function of pore fraction, orientation and connectivity.

\subsubsection{Static Young's modulus}

At ambient temperatures, the static Young's modulus decreases from $>15$ to $<5 \mathrm{GPa}$ with increasing porosity (Fig. 10c). This is an indication that samples with lower porosities were stiffer than those with higher porosities.
However, there were outliers to the data trend: UNZ-13 and UNZ-2 (with average porosities of 0.32 and 0.13 , respectively) are stiffer and have higher (> 5 GPa) Young's moduli than other rocks with similar porosities (see Table 1); in UNZ-13, this may be explained by the preferred orientation of pores parallel to the principal stress (Fig. 3a) (see Griffiths et al., 2017). The naturally altered samples, tested at similar conditions, exhibited Young's modulus trends like those of comparable fresh rocks (Fig. 10c).

Lavas deformed at $900^{\circ} \mathrm{C}$ at a strain rate of $10^{-3} \mathrm{~s}^{-1}$ have systematically lower $(\sim 5-10 \mathrm{GPa})$ Young's moduli. It is this malleability that allows the lava to be deformed to higher strains before macroscopic failure (Fig. 10b), an observation recognised in Schaefer et al. (2015) in tests on basaltic lavas.

In addition, thermally stressed samples have slightly lower $(\sim 0.5-1.5 \mathrm{GPa})$ Young's moduli than their unstressed equivalents, as previously noted in dacites from Mount St. Helens (Kendrick et al., 2013a) and andesites from Colima volcano (Heap et al., 2014a). The slight decrease in static Young's 

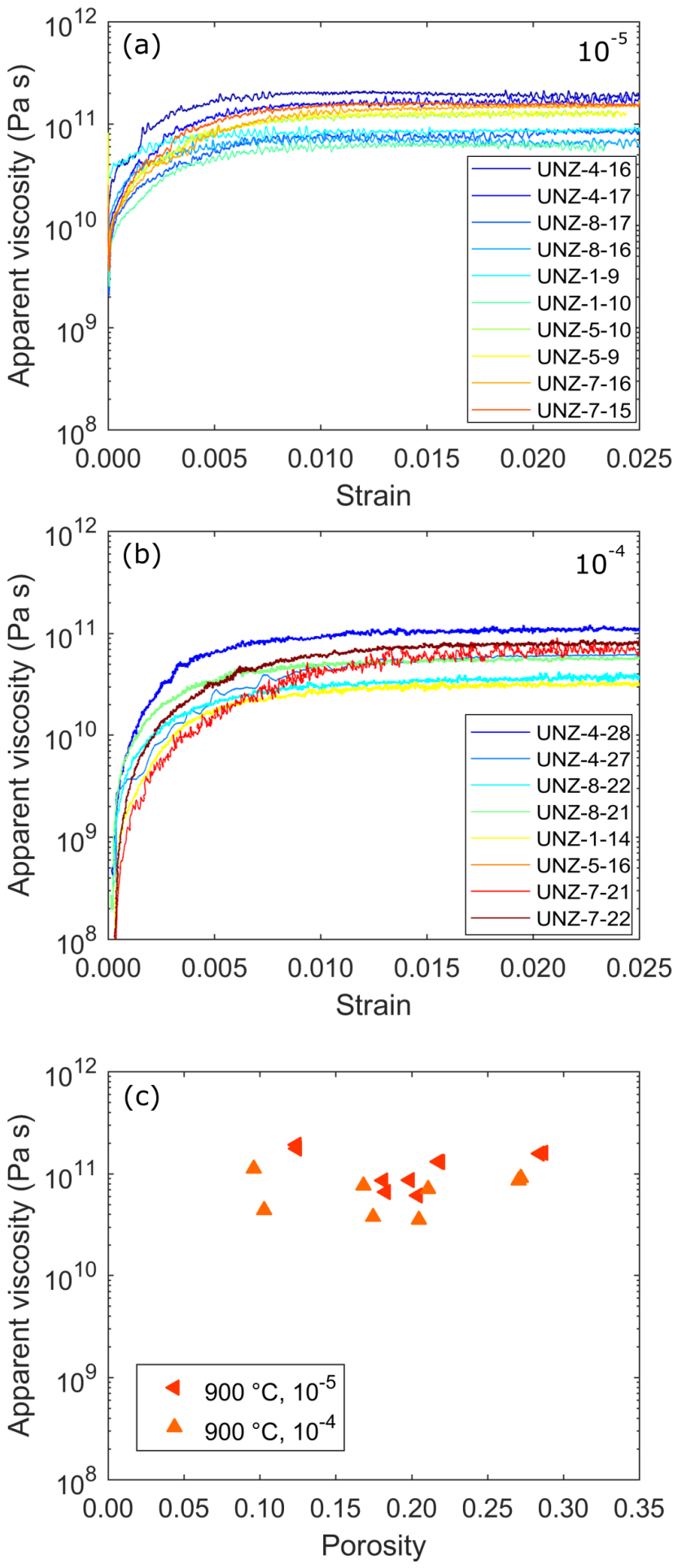

Figure 9. Apparent viscosities of porous lavas at $900^{\circ} \mathrm{C}$ for strain rates of (a) $10^{-5}$ and (b) $10^{-4} \mathrm{~s}^{-1}$; colours warm from blue to red with increasing sample porosity. (c) Compilation of apparent viscosities as a function of porosity for samples tested at strain rates of $10^{-4}$ and $10^{-5} \mathrm{~s}^{-1}$. Viscosities decrease between strain rates of $10^{-5}$ and $10^{-4} \mathrm{~s}^{-1}$, an example of shear thinning in the Unzen samples. Porosity has no control on the apparent viscosities of the samples tested here. modulus with thermal stresses highlights a potential change in porosity distribution that was not recognised by other means (e.g. total porosity, strength).

\subsubsection{The effect of temperature on sample strength}

Remarkably, when in the brittle regime at high temperature, samples exhibited strengths $\sim 10-40 \mathrm{MPa}$ greater than at ambient temperature. This may be attributed to the way the samples respond to stress at higher temperatures. First, upon heating a rock, it expands, which may partially close preexisting microfractures, thus modifying the resultant elastic response of the material (see Sect. 4.1.2). Moreover, at $900{ }^{\circ} \mathrm{C}$ the presence of interstitial melt in a sample allows for considerably more strain than if it were deformed at ambient temperature (when in a solid, glassy state). The initial strain upon loading would be accommodated by both an instantaneous and a delayed elastic response (e.g. Dingwell and Webb, 1989) and perhaps minor microcrack closure (e.g. Heap et al., 2014a) before the onset of viscous (e.g. Lavallée et al., 2007) and crystal plastic (e.g. Kendrick et al., 2017) deformation that results in permanent strain (and barrelling of the sample). Thus, at higher temperatures, more strain is accommodated upon loading than at ambient temperature (Fig. 7a), leading to higher strain to failure (Fig. 10b) and lower Young's moduli than their rock counterparts (Fig. 10c). The Young's moduli for lavas undergoing failure at high temperature are rate dependent, perhaps as they may undergo further stress dissipation by viscous relaxation in the melt.

A similar increase in strength with temperature was also noted in basaltic rocks from Pacaya volcano (Schaefer et al., 2015). There, the authors attributed the increase in strength of the glass-poor rock to the closure of microcracks (likely formed upon cooling after their eruption) due to thermal expansion, a process that equally occurs in Mt. Unzen dome rocks. Rocks may also become weaker from thermal stressing; this can be due to crack initiation (Heap et al., 2016a) or alteration, via processes such as decarbonation and dehydroxylation (Heap et al., 2012, 2013a, b). A recent study by Eggertsson et al. (2018) found that samples that hosted microfractures (like Mt. Unzen dome rock) were not affected by thermal stressing, while those that showed a trivial fraction of pre-existing microfractures were more readily fractured through thermal stressing and as a result became more permeable.

\section{Rheology of dome lavas}

\subsection{Viscosity of dome lavas}

The style of an eruption - effusive vs. explosive - depends on the rheological response of magma (Dingwell, 1996). The urge to understand the alarmingly variable nature of volcanoes and recent advances in experimental capabilities and computational modelling have encouraged the community 

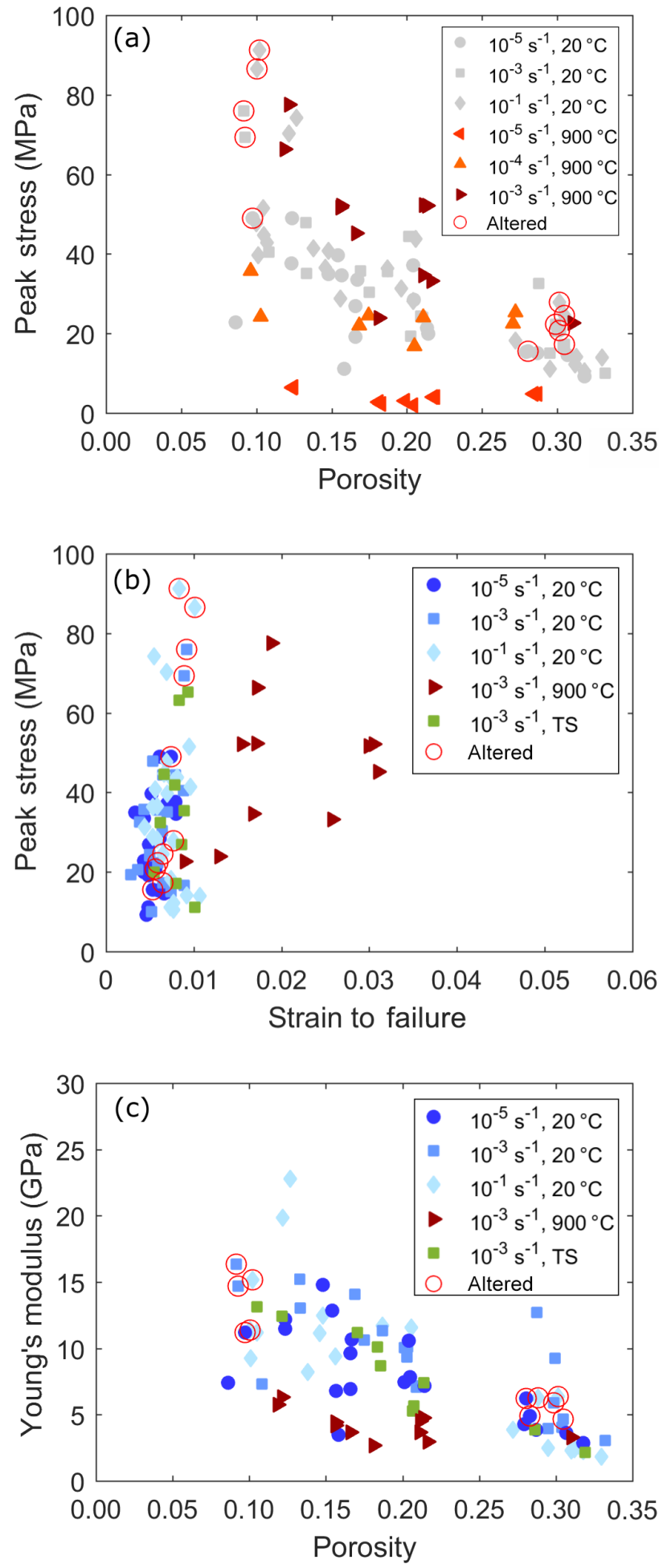

Figure 10. Strength and Young's moduli of Unzen rocks and lavas at different conditions. Shades of blue represent tests carried out at ambient temperatures, shades of red indicate those performed at $900^{\circ} \mathrm{C}$ and green depicts thermally stressed samples which were tested in ambient conditions. The red rings circle the samples which were deemed visibly altered at collection. (a) Peak stress with porosity for all completed experiments. Low-temperature tests, as seen in Fig. 5a, are faded to grey. (b) Peak stress with strain at the point of sample failure (i.e. the strain at peak stress) for all experiments with a brittle response. (c) Young's modulus as a function of porosity for all samples that had a brittle response, calculated using the slope of the linear portion of the stress-strain curve (see Fig. S6). 


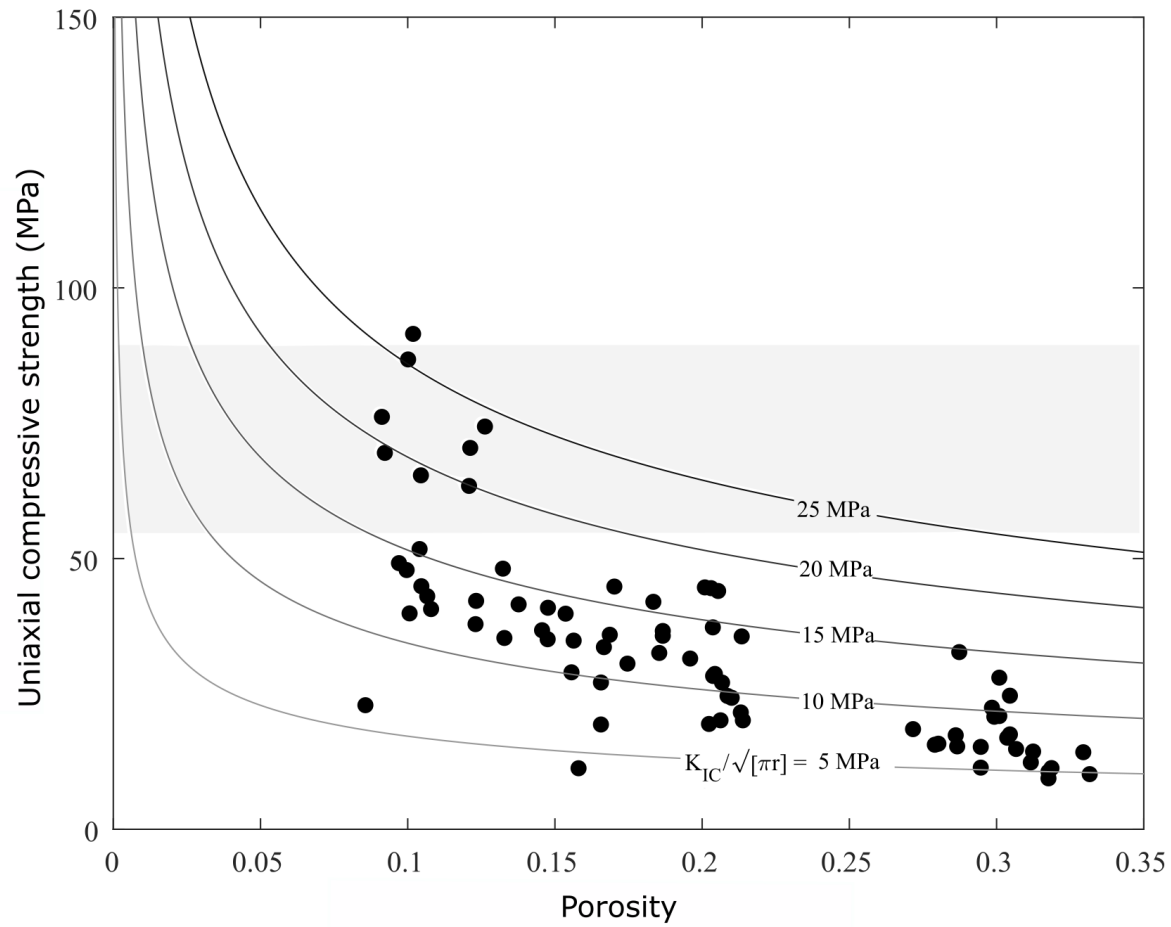

Figure 11. Plot of uniaxial compressive stress against porosity showing the ambient temperature mechanical data (black dots) alongside contours of various values of $\frac{K_{\mathrm{IC}}}{\sqrt{\pi r}}(5-25 \mathrm{MPa})$ from the pore-emanating crack model (Eq. 3). The range of UCS given by the wing-crack model is also plotted as a shaded region. The mechanical data are cross-cut by the contours, suggesting a change in the dominant porous structure. At porosities $>0.25$ the UCS given by the pore-emanating crack model with $\frac{K_{\mathrm{IC}}}{\sqrt{\pi r}}=5-10 \mathrm{MPa}$ seems to fit the data well. For porosities ranging from 0.12 to 0.2 the UCS given by the pore-emanating crack model with $\frac{K_{\mathrm{IC}}}{\sqrt{\pi r}}=10-15 \mathrm{MPa}$ encloses the data. The UCS for the densest rocks in the study $(\sim 0.08-0.12)$ would suggest yet a higher $\frac{K_{\mathrm{IC}}}{\sqrt{\pi r}}$ of $20-25 \mathrm{MPa}$. For porosities $<0.1$ the UCS given by the wing-crack model is similar to the mechanical data $(\sigma=54.2-89.7 \mathrm{MPa})$.

to focus efforts on the development of two- and three-phase models of magma rheology (e.g. Lejeune and Richet, 1995; Caricchi et al., 2007; Lavallée et al., 2007; Costa et al., 2009; Mueller et al., 2011b; Truby et al., 2015). Truby et al. (2015) combined two two-phase flow models (considering melt and crystals, and melt and gas bubbles) to elaborate a three-phase model of magmatic suspensions, further tested against a set of controlled analogue laboratory data. Their model shows that while the addition of crystals increases the viscosity of a suspension, leading to a shear thinning rheology, the addition of gas bubbles (which can deform during shear) has variable consequences. Depending upon the initial crystal volume and maximum packing fraction of those crystals, the addition of gas bubbles may result in a further increase in viscosity or, in other cases, a levelling or a decrease in the apparent viscosity of the suspension. Their model suggests that the addition of bubbles to lavas, above their glass transition, with high normalised crystal fractions, like those seen in volcanic domes, would likely decrease the viscosity of the suspension. However, here, the data show that the presence of vesicles (between 0.09 and 0.33 ) in dome lavas may not necessar- ily influence the apparent viscosity (at least not systematically). We advance that this could be due to the high connectivity of the pores present in dome lavas, which allows efficient outgassing; thus the gas cannot act as an isolated phase that can pressurise during shear. Thus, it may be that lavas hosting permeable porous networks may have mostly porosity-independent apparent viscosities (at least across the range examined here), as suggested by Lavallée et al. (2007). Current models relating porosity to viscosity simply account for the presence of isolated gas bubbles via a capillary number to calculate the apparent viscosity of a multiphase suspension (e.g. Rust and Manga, 2002; Llewellin and Manga, 2005; Truby et al., 2015). However, this result highlights important shortcomings to the modelling of shallow magmas, in which porous networks tend to develop connectivity, especially in sheared crystal-bearing lavas (e.g. Laumonier et al., 2011; Kushnir et al., 2017). This connectivity controls outgassing, and thus pressure build-up or release, which is responsible for rheological variations in magma and therefore eruption style (effusive vs. explosive). Our findings suggest that we need to revise three-phase models to account for gas 
flow through evolving deformable bubbles, which may also be connected, in order to constrain the apparent viscosity of magmas in lava domes and other open-system settings.

\subsection{Failure criterion for porous lavas}

During magma ascent, the strain rate, which is proportional to effusion rate (e.g. Goto, 1999), plays a key role in determining whether the response of magmas and extruding lavas is that of a solid or liquid (Webb and Dingwell, 1990). Here, the macroscopic deformation mode (viscous, viscousdominated transitional, brittle-dominated transitional or brittle) of lavas was characterised based on their resulting stressstrain curve (Sect. 3.2.2; Fig. 12a); these are further supported by microstructural observations (see Figs. 6, 12a). Note that sample UNZ-4-28 was not given a classification as its response to deformation was likely an experimental artefact due to a chipping of the sample edge. The distinction among these rheological regimes can be made using the Deborah number (Eq. 2). In a recent study on the failure of single-phase silicate melts, Wadsworth et al. (2017) suggest that fractures can propagate above $D e \geq 10^{-2}$ when a sample begins to undergo brittle deformation, although these fractures are often blunted by viscous relaxation. When $D e \geq 1$ brittle behaviour dominates over viscous deformation and violent rupture of the sample ensues. This dimensionless ratio of the relaxation timescale of the melt (Eq. 1) and the observation timescale can be rewritten as

$D e=\frac{\eta_{\mathrm{m}}}{G_{\infty} t_{\mathrm{obs}}}$,

where the observation time, $t_{\mathrm{obs}}$, is the inverse of the strain rate of magma deformation, $\dot{\varepsilon}_{\text {obs }}$. Thus Eq. (10) can be rewritten as

$D e=\frac{\dot{\varepsilon}_{\text {obs }} \eta_{\mathrm{m}}}{G_{\infty}}$.

Magmatic suspensions, like those described in this study, are non-Newtonian materials with a shear thinning response (Caricchi et al., 2007; Lavallée et al., 2007; Cordonnier et al., 2009; Avard and Whittington, 2012; Vona et al., 2013); hence their viscosity is strain rate dependent. It has previously been described that the peak stress, $\sigma$, shares a power-law relationship with strain rate, $\dot{\varepsilon}_{\exp }$, via

$\sigma=k \dot{\varepsilon}_{\mathrm{obs}}^{b}$,

where $b$ is the flow behaviour index and $k$ is the flow consistency index $\left(\mathrm{Pa}^{b}\right)$, describing the rheology of the fluids (Ostwald, 1925; Lavallée et al., 2007; Jahangiri et al., 2012). For Newtonian bodies $b=1$, but for shear thinning suspensions, $b$ decreases below 1 (Caricchi et al., 2007) and reaches a minimum of $b=0.5$ for crystal-rich materials (Lavallée et al., 2007; Cordonnier et al., 2009). In the present study the Mt. Unzen dome material tested at $900^{\circ} \mathrm{C}$, by fitting a power law to the peak stress-strain curve, we obtained Ostwald constants of $k=1653$ and $b=0.5$ (Fig. 12b). Thus, we can rewrite Eq. (11), using Eq. (12), to obtain

$D e=\frac{(\sigma / k)^{1 / b} \eta_{\mathrm{m}}}{G_{\infty}}$,

which permits the representation of the Deborah number of material failure as a function of strength (which was shown to be dependent on porosity), for a given temperature (and thus interstitial melt viscosity). For our samples, the interstitial melt viscosity can be estimated at $10^{9.42} \mathrm{~Pa}$ s (using its chemistry and experimental temperature as an input parameter in the viscosity calculator of Giordano et al., 2008). In Fig. 12c, we present the data using symbols that illustrate the response of the samples. The onset of transitional behaviour, termed viscous-dominated transitional, is marked by the red line. Similarly, the onset of brittle behaviour, brittledominated transitional, is marked by the yellow line. These lines are linear regressions on a semi-log space plot, with their standard error of estimates marked by faded colour windows. Any point that plots between the red and yellow lines would be termed transitional and could demonstrate any type of hybrid behaviour. Above a porosity of 0.27 no transitional zone occurs, and behaviour would be classified as either viscous or brittle. This analysis demonstrates that the critical Deborah number, $D e_{\mathrm{c}}$, which indicates the initiation of rupture, in dome lavas from Mt. Unzen decreases by just over half an order of magnitude over a 0.35 range in porosity; from $\sim 7.65 \times 10^{-5}$ in the densest sample measured to $4.1 \times 10^{-5}$ in the most porous, following the trend $D e_{\mathrm{c}}=-1.7 \times 10^{-4} \varphi+9.40 \times 10^{-5}$ (Fig. 12c). Such a magnitude is proportional to the strength decrease in material as a function of porosity (see Fig. 10a and Paterson and Wong, 2005 , for a discussion) and thus relates the porosity to the ability of high-temperature lavas to rupture. By extrapolating the trend and finding the $D e_{\mathrm{c}}$ for a hypothetical, pore-free Mt. Unzen sample, we can compare our results to a twophase (crystals and melt) model for rupture (Wadsworth et al., 2017). Given that the Mt. Unzen material has a crystal content (microlites and phenocrysts), $\phi_{x}$, of $\sim 0.75$, the bulk $D e_{\mathrm{c}}$ can be modelled via

$D e_{\mathrm{c}}=D e_{\mathrm{c} x}\left(1-\frac{\phi_{x}}{\phi_{\mathrm{m}}}\right)$,

where $D e_{c x}$ is the critical Deborah number for a crystal- and bubble-free melt, $10^{-2}$, and $\phi_{\mathrm{m}}$ is the maximum packing fraction of the system.

For the Mt. Unzen material $\phi_{\mathrm{m}}$ can be assumed to be in the range of $\sim 0.76->0.99$, as it is clear from microstructural analysis that our material has not yet reached $\phi_{\mathrm{m}}$ (see Fig. 3) (maximum packing is defined geometrically as the volume fraction at which there is no space remaining for further particles; Mader et al., 2013). This gives a modelled $D e_{\mathrm{c}}$ in the range of $\sim 1 \times 10^{-4}$ to $7.6 \times 10^{-4}$ which is in line with 


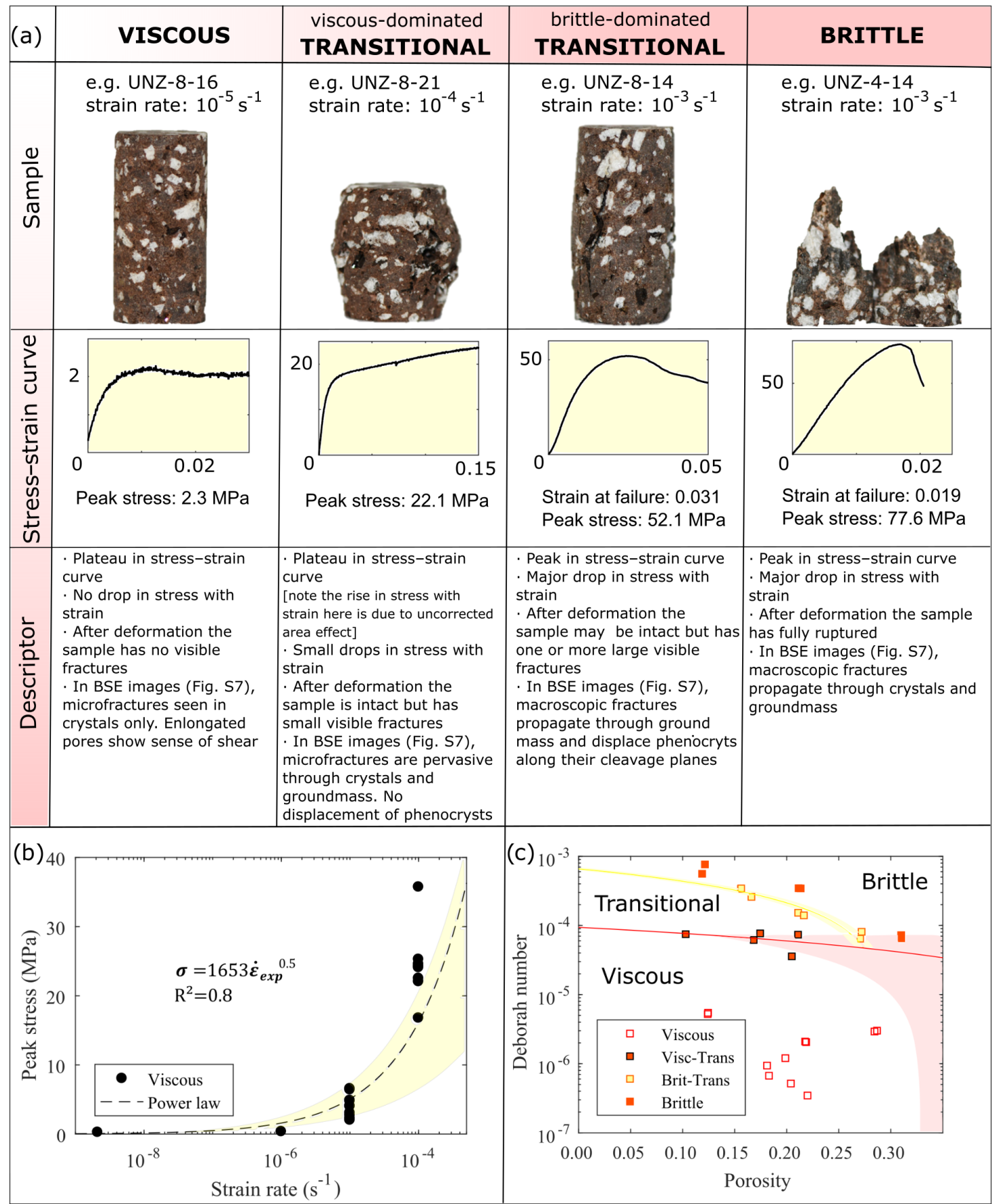

Figure 12. (a) A schematic demonstration of sample rheological classification (viscous, viscous-dominated transitional, brittle-dominated transitional or brittle), depending on the respective shape of the stress-strain curve and the amount of strain experienced. (b) Peak stress plotted with strain rate for completed experiments in semi-log space. The power-law equation of the line is shown in the figure. Ostwald constants $k$ and $b$ are 1653 and 0.5 , respectively. The standard error of estimate is shown on the plot as the yellow window, along with the $R^{2}$ value. (c) The calculated Deborah number as a function of porosity for each sample tested at high temperature, in semi-log space. The viscous-dominated transitional behaviour is marked by the red line bordered by a red window showing the standard estimate of error. The brittle-dominated transitional behaviour is marked by the yellow line bordered by a yellow window showing the standard estimate of error. The critical Deborah number, $D e_{c}$, can thus be said to be between $1 \times 10^{-4}$ and $6.6 \times 10^{-4}$ for dense (pore-free) crystal-rich dome lavas, deceasing linearly with the addition of pores. We find that the two transitional zones converge at a porosity of approximately 0.27 , beyond which, no transition zone exists (although this coincides with the limit of the material properties studied). Note that sample UNZ-4-28 was omitted from this plot as its resulting stress-strain curve was likely due to an experimental artefact caused by chipping of the sample edge. 
the $D e_{\mathrm{c}}$ found by the linear extrapolation of experimental results, $9.4 \times 10^{-5}$ for the onset of rupture and $6.6 \times 10^{-4}$ for full rupture (Fig. 12c).

Thus, both the addition of crystals (as seen by the fact that $D e_{\mathrm{c}}$ of dense dome lavas is reduced by over 1 order of magnitude compared to that suggested by Dingwell and Webb, 1990) and vesicles (as shown by the above equation) contribute to an increased brittleness of lava during ascent and eruption at lava domes, and in many other eruptive scenarios.

\section{Implications for volcanic scenarios}

The findings observed here help constrain the impact of rheological evolution on lava domes as they erupt and cool following emplacement. The rheology of magma has a fundamental influence on the style of a volcanic eruption, be it explosive or effusive (Dingwell, 1996; Gonnermann and Manga, 2007). Understanding how magmas respond to changes in petrology, stress and eruptive shearing conditions that occur during ascent in a volcanic conduit may help to enhance models that aim to predict volcanic activity. The work undertaken here constrains the material behaviour of erupting dome lavas and the relics that remain once the lava cools.

As magma crystallises, its apparent viscosity (generally) increases as the melt evolves, and an increasing fraction of the suspension becomes solid (with slower diffusivity and a lower rate of plasticity than the viscous liquid melt); thus the suspension becomes increasingly solid-like. For crystalline magmas, we would expect $D e_{\mathrm{c}}$ to be lower than that for silicate liquids (i.e. $D e_{\mathrm{c}}<10^{-2}$; e.g. Gottsmann et al., 2009). Cordonnier et al. (2012a, b) constrained the failure of silicate liquids with different crystal fractions, and they indeed showed that $D e_{\mathrm{c}}$ decreases when crystallinity increases. They suggest that $D e_{\mathrm{c}}$ linearly decreases from $10^{-2}$ to $2 \times 10^{-3}$ between 0 and 60 vol \% crystals. However, the viscosity used to estimate Maxwell's relaxation rate in the De analysis was based on the suspension's apparent viscosity rather than the interstitial melt viscosity. To constrain how the addition of crystals shifts the onset of failure of a material whose rheology is well known, it is advantageous to consider the pure melt. Given this, an even larger decrease in $D e_{\mathrm{c}}$ would be observed (perhaps down to $\sim 9.4 \times 10^{-5}$ as constrained by failure of our densest lavas). Since the strength of material is known to be strongly influenced by the presence of pores (commonly vesicles in volcanic materials) and microfractures (e.g. Paterson and Wong, 2005, for a review of material properties in the brittle field), here we demonstrate that the addition of porosity to magma shifts failure to lower strain rates; thus, under constant ascent conditions, magma may undergo failure simply by vesiculation, without the need for any increase in strain rate.

Upon extrusion, lava cools, contracts and fractures (Lamur et al., 2018). Here we show that the strength of a dome is re- duced upon cooling due to contraction and microfracturing, leaving a weaker relic structure. This situation may favour the progressive creep of cooling dome structures, as observed in lobe 11 at Mt. Unzen (Kohashi et al., 2012).

Post-emplacement, through time and prolonged exposure to corrosive fluids, dome material may alter (Ball et al., 2015). In this study, the altered rocks tested showed a higher strength than pristine rocks with equivalent porosities. However, previous studies have found that altered volcanic rocks can also be weaker (e.g. Pola et al., 2012). From this distinction we surmise that the structure of the rocks as well as the type of alteration (developing under different conditions in cooling volcanic rocks) may have a contrasting effect on the strength of cooled dome lavas. Thus, the data shown here beg for an increased focus on the impact of alteration on volcanic rock strength for improved lava dome structural stability models.

The rate of deformation imposed on dome materials is also an important variable to be considered. In this study, and in others (e.g. Schaefer et al., 2015; Lavallée et al., 2018), volcanic rocks have been shown to withstand higher stresses when deformed at higher strain rates. Previous studies have suggested earthquakes with high ground acceleration have provoked lava dome collapse (Voight, 2000); therefore, it is essential to understand the effect of strain rate on the strength of materials. This is of particular importance for Mt. Unzen as it is located in a very seismically active area. Slow, continuous strain (or recurring stressing cycles) can induce fatigue in a material and promote brittle creep (e.g. Heap and Faulkner, 2008; Heap et al., 2009; Brantut et al., 2013; Kendrick et al., 2013a; Schaefer et al., 2015); thus weakening the rocks which undergo failure at lower stresses. Thus, over long periods (years) of deformation, such as for lobe 11 at Mt. Unzen, the actual strength of the dome rocks may be lower than those reported here at the lowest strain rate of $10^{-5} \mathrm{~s}^{-1}$ ). Time-dependent deformation can importantly contribute to catastrophic collapse of volcanic structures (e.g. Mt. St. Helens; Reid et al., 2010). Here we advance that it is crucial for future failure models of volcanic materials to incorporate the effect of strain rate.

Volcanic structures are made of heterogeneous rocks and lavas, with intricate mineralogical assemblages, textures and fabrics, with variable degrees of coherence; thus, their mechanical responses may vary widely. Although here we have only tested material from the 1991-1995 eruption of Mt. Unzen, this study has the potential to be applied to other domeforming volcanoes of similar composition, crystallinity and porosity. Additionally, the work can also be applied to parts of larger volcanic edifices dominantly constructed by the accumulation of lavas, which may be prone to collapse (Ball et al., 2015). The work presented here can help constrain the behaviour of lavas and rocks involved in lava dome eruptions. We anticipate that the results will form the basis for more advanced numerical simulations of dome eruption and related hazards. 


\section{Conclusion}

Uniaxial experiments carried out at ambient and high temperature $\left(900^{\circ} \mathrm{C}\right)$ on a suite of natural lavas from Mt. Unzen have given significant insight into the behaviour of lava domes, both during extrusion and after emplacement. Ambient temperature experiments allowed for the investigation of brittle behaviour, and results from these experiments can be applied to cooling domes (and the relics that they leave in the record), allowing the development of volcanic edifice failure models. Conclusions drawn from experimentation are as follows.

1. In the brittle regime, strength decreases with increasing pore volume at both ambient and high temperatures.

2. Magmas deformed in the brittle regime at high temperature are stronger than rocks of equivalent porosity deformed at ambient temperature.

3. Thermal stressing did not affect the strength of dome rocks within the conditions tested $\left(<900^{\circ} \mathrm{C}\right.$ and $4{ }^{\circ} \mathrm{C} \mathrm{min}-1$ ); it did however change the morphology of the stress-strain curve, indicating the widening of cracks.

4. The presence of alteration may have variable effects, sometimes strengthening volcanic rocks.

5. The strength of rocks and lavas (in the brittle field at high temperature) increases with strain rate.

6. The viscosity of dome lavas decreased with strain rate (shear thinning) and did not vary for the range of material crystallinity and porosity studied.

7. Lavas deformed at high temperature and strain rates of $>10^{-4} \mathrm{~s}^{-1}$ become increasingly brittle and adopt fully brittle response above $10^{-3} \mathrm{~s}^{-1}$.

8. The critical Deborah number, $D e_{\mathrm{c}}$, of dense dome lavas was found to be ca. $1 \times 10^{-4}$. It decreases with porosity according to a linear relationship $D e_{\mathrm{c}}=-1.7 \times 10^{-4} \varphi+$ $9.40 \times 10^{-5}$.

These results reveal that current stability models of cooling lava domes, like that of lobe 11 at Mt. Unzen, require an integration of the complex nature of the materials. The outcome of this study suggests that, as a primary control on rock strength, porosity heterogeneities must be included when modelling failure mechanisms. As secondary controls, it would also be beneficial to include deformation conditions such as temperature and strain rate. Conclusions drawn from high-temperature experiments suggest that current three-phase models may not be fully applicable to dome lavas and other crystal-rich lavas. We suggest a new formulation of the Deborah number that applies to porous crystalrich lavas and propose that it may help refine the accuracy of models attempting to describe rheological evolution to explain geophysical data monitored during lava dome eruptions.

Code and data availability. Supplementary data are available in the Supplement Figs. S1 to S6. The script for the Young's modulus calculation is freely available on GitHub (Coats, 2018). Further information can be obtained upon request to the corresponding author. The AST14DEM used in Fig. 1 was retrieved from the online data pool, courtesy of Land Processes Distributed Active Archive Center (LP DAAC) and the NASA the Japan Ministry of Economy, Trade and Industry (METI), (https://lpdaac.usgs.gov/dataset_discovery/aster/aster_ products_table/ast14dem_v003\#tools, last access: 29 October 2018).

Supplement. The Supplement related to this article is available online at: https://doi.org/10.5194/se-9-1299-2018-supplement.

Author contributions. YL and JEK designed the experiments. RC AJH, TMi, JEK, PAW and JDA carried out the mechanical experiments and physical measurements. PAW collected microprobe data and conducted softening point determination. $\mathrm{RC}$ wrote the processing codes, analysed the data and prepared the paper with contributions from all co-authors. RC, JEK, PAW, TMi, AJH, JDA, TMa and YL contributed to the collection and selection of samples and preparation of the paper.

Competing interests. The authors declare that they have no conflict of interest.

Acknowledgements. Rebecca Coats, Jackie E. Kendrick, Paul A. Wallace, Adrian J. Hornby, Takahiro Miwa, James D. Ashworth and Yan Lavallée acknowledge funding from the European Research Council (ERC) Starting Grant on Strain Localisation in Magma (SLiM; no. 306488). Jackie E. Kendrick was supported by an Early Career Fellowship of the Leverhulme Trust. Paul A. Wallace acknowledges the NERC ATSC training for providing time to conduct EPMA measurements. Fieldwork was funded by the DAIWA Anglo-Japanese Foundation (grant number 11000/11740). The authors would like to thank Hiroshi Shimizu for his guidance throughout the study.

Edited by: Joachim Gottsmann

Reviewed by: Steve Quane and Jamie Farquharson

\section{References}

Al-Harthi, A. A., Al-Amri, R. M., and Shehata, W. M.: The porosity and engineering properties of vesicular basalt in Saudi Arabia, Eng. Geol., 54, 313-320, https://doi.org/10.1016/S00137952(99)00050-2, 1999. 
Almberg, L. D., Larsen, J. F., Eichelberger, J. C., Vogel, T. A., and Patino, L. C.: Comparison of eruptive and intrusive samples from Unzen Volcano, Japan: Effects of contrasting pressuretemperature-time paths, J. Volcanol. Geoth. Res., 175, 60-70, https://doi.org/10.1016/j.jvolgeores.2008.03.020, 2008.

Ashby, M. F. and Sammis, C. G.: The damage mechanics of brittle solids in compression, Pure Appl. Geophys., 133, 489-521, https://doi.org/10.1007/BF00878002, 1990.

Ashwell, P. A., Kendrick, J. E., Lavallée, Y., Kennedy, B. M., Hess, K., Von Aulock, F. W., Wadsworth, F. B., Vasseur, J., and Dingwell, D. B.: Permeability of compacting porous lavas, J. Geophys. Res.-Sol. Ea., 120, 1605-1622, https://doi.org/10.1002/2014JB011519, 2015.

Avard, G. and Whittington, A. G.: Rheology of arc dacite lavas: experimental determination at low strain rates, B. Volcanol., 74, 1039-1056, https://doi.org/10.1007/s00445-012-0584-2, 2012.

Ball, J. L., Stauffer, P. H., Calder, E. S., and Valentine, G. A.: The hydrothermal alteration of cooling lava domes, B. Volcanol., 77, 1-16, https://doi.org/10.1007/s00445-015-0986-z, 2015.

Barmin, A., Melnik, O., and Sparks, R. S. J.: Periodic behavior in lava dome eruptions, Earth Planet. Sc. Lett., 199, 173-184, https://doi.org/10.1016/S0012-821X(02)00557-5, 2002.

Baud, P., Wong, T.-F., and Zhu, W.: Effects of porosity and crack density on the compressive strength of rocks, Int. J. Rock Mech. Min., 67, 202-211, https://doi.org/10.1016/j.ijrmms.2013.08.031, 2014.

Brace, W. F., Paulding, B. W., and Scholz, C.: Dilatancy in the fracture of crystalline rocks, J. Geophys. Res., 71, 3939-3953, https://doi.org/10.1029/JZ071i016p03939, 1966.

Brantut, N., Heap, M. J., Meredith, P. G., and Baud, P.: Time-dependent cracking and brittle creep in crustal rocks: A review, J. Struct. Geol., 52, 17-43, https://doi.org/10.1016/j.jsg.2013.03.007, 2013.

Bubeck, A., Walker, R. J., Healy, D., Dobbs, M., and Holwell, D. A.: Pore geometry as a control on rock strength, Earth Planet. Sc. Lett., 457, 38-48, https://doi.org/10.1016/j.eps1.2016.09.050, 2017.

Calder, E. S., Luckett, R., Sparks, R. S. J., and Voight, B.: Mechanisms of lava dome instability and generation of rockfalls and pyroclastic flows at Soufrière Hills Volcano, Montserrat, Geol. Soc. Mem., 21, 173-190, 2002.

Calder, E. S., Lavallée, Y., Kendrick, J. E., and Bernstein, M.: Lava Dome Eruptions, in: The Encyclopedia of Volcanoes, edited by: Sigurdsson, H., Houghton, B., Rymer, H., Stix, J., and McNutt, S., Elsevier, Academic Press, London, UK, 343-362, 2015.

Caricchi, L., Burlini, L., Ulmer, P., Gerya, T., Vassalli, M., and Papale, P.: Non-Newtonian rheology of crystal-bearing magmas and implications for magma ascent dynamics, Earth Planet. Sc. Lett., 264, 402-419, https://doi.org/10.1016/j.epsl.2007.09.032, 2007.

Cashman, K. V.: Groundmass crystallization of Mount St. Helens dacite, 1980-1986: a tool for interpreting shallow magmatic processes, Contrib. Mineral. Petr., 109, 431-449, https://doi.org/10.1007/BF00306547, 1992.

Cashman, K. V. and Sparks, R. S. J.: How volcanoes work: A 25 year perspective, Bull. Geol. Soc. Am., 125, 664-690, https://doi.org/10.1130/B30720.1, 2013.

Castro, J. M., Manga, M., and Martin, M. C.: Vesiculation rates of obsidian domes inferred from $\mathrm{H}_{2} \mathrm{O}$ concentration profiles, Geophys. Res. Lett., 32, 1-5, https://doi.org/10.1029/2005GL024029, 2005.

Coats, R.: Young's Modulus for UCS, Zenodo, https://doi.org/10.5281/zenodo.1287237, 2018.

Cole, P. D., Calder, E. S., Druitt, T. H., Hoblitt, R., Robertson, R., Sparks, R. S. J., and Young, S. R.: Pyroclastic flows generated by gravitational instability of the 1996-97 lava dome of Soufriere Hills Volcano, Montserrat, Geophys. Res. Lett., 25, 3425-3428, 1998.

Collombet, M., Wadsworth, F. B., Gurioli, L., Scheu, B., Kueppers, U., Di Muro, A., and Dingwell, D. B.: The evolution of pore connectivity in volcanic rocks, Earth Planet. Sc. Lett., 462, 99109, https://doi.org/10.1016/j.epsl.2017.01.011, 2017.

Cordonnier, B., Hess, K., Lavallée, Y., and Dingwell, D. B.: Rheological properties of dome lavas: Case study of Unzen volcano, Earth Planet. Sc. Lett., 279, 263-272, https://doi.org/10.1016/j.epsl.2009.01.014, 2009.

Cordonnier, B., Caricchi, L., Pistone, M., Castro, J. M., Hess, K., Gottschaller, S., Manga, M., Dingwell, D. B., and Burlini, L.: The viscous-brittle transition of crystal-bearing silicic melt: Direct observation of magma rupture and healing, Geology, 40, 611-614, https://doi.org/10.1130/G3914.1, 2012a.

Cordonnier, B., Schmalholz, S. M., Hess, K., and Dingwell, D. B.: Viscous heating in silicate melts: An experimental and numerical comparison, J. Geophys. Res.-Sol. Ea., 117, 1-13, https://doi.org/10.1029/2010JB007982, 2012b.

Costa, A., Caricchi, L., and Bagdassarov, N.: A model for the rheology of particle-bearing suspensions and partially molten rocks, Geochem. Geophy. Geosy., 10, 1-13, https://doi.org/10.1029/2008GC002138, 2009.

de Silva, S. and Lindsay, J. M.: Primary Volcanic Landforms, in: The Encyclopedia of Volcanoes, edited by: Sigurdsson, H., Houghton, B., McNutt, S., Rymer, H., and Stix, J., Elsevier, Academic Press, San Diego, California, USA, 273-298, 2015.

Deubelbeiss, Y., Kaus, B. J. P., Connolly, J., and Caricchi, L.: Potential causes for the non-Newtonian rheology of crystal-bearing magmas, Geochem. Geophy. Geosy., 12, 1-22, https://doi.org/10.1029/2010GC003485, 2011.

Dingwell, D. B.: Volcanic Dilemma: Flow or Blow?, Science, 273, 1054-1055, https://doi.org/10.1126/science.273.5278.1054, 1996.

Dingwell, D. B. and Webb, S. L.: Structural relaxation in silicate melts and non-Newtonian melt rheology in geologic processes, Phys. Chem. Miner., 16, 508-516, https://doi.org/10.1007/BF00197020, 1989.

Dingwell, D. B. and Webb, S. L.: Relaxation in silicate melts, Eur. J. Mineral., 2, 427-449, https://doi.org/10.1127/ejm/2/4/0427, 1990.

Eggertsson, G. H., Lavallée, Y., Kendrick, J. E., and Markússon, S.: Improving fluid flow in geothermal reservoirs by thermal and mechanical stimulation: The case of Krafla volcano, Iceland, J. Volcanol. Geoth. Res., https://doi.org/10.1016/j.jvolgeores.2018.04.008, in press, 2018.

Einstein, A.: A new determination of the molecular dimensions (Translation of the 1906 German version), Ann. Phys., 34, 591$592,1911$. 
Elsworth, D. and Voight, B.: Evaluation of volcano flank instability triggered by dyke intrusion, Geol. Soc. Spec. Publ., 110, 45-53, https://doi.org/10.1144/GSL.SP.1996.110.01.03, 1996.

Farquharson, J. I., Heap, M. J., Varley, N. R., Baud, P., and Reuschlé, T.: Permeability and porosity relationships of edifice-forming andesites: A combined field and laboratory study, J. Volcanol. Geoth. Res., 297, 52-68, https://doi.org/10.1016/j.jvolgeores.2015.03.016, 2015.

Farquharson, J. I., Heap, M. J., Baud, P., Reuschlé, T., and Varley, N. R.: Pore pressure embrittlement in a volcanic edifice, B. Volcanol., 78, 6, https://doi.org/10.1007/s00445-015-0997-9, 2016.

Fink, J. H. and Anderson, S. W.: Lava domes and coulees, in: The Encyclopedia of Volcanoes, edited by: Sigurdsson, H., Houghton, B., Rymer, H., Stix, J., and McNutt, S., Academic Press, San Diego, California, USA, 307-318, 2000.

Fluegel, A.: Glass viscosity calculation based on a global statistical modelling approach, Glas. Technol. J. Glas., 48, 13-30, available at: http://glassproperties.com/viscosity/ (last access: 29 October 2018), 2007.

Gent, A. N.: Theory of the parallel plate viscometer, Br. J. Appl. Phys., 11, 85-87, https://doi.org/10.1088/0508-3443/11/2/310, 1960.

Giordano, D., Russell, J. K., and Dingwell, D. B.: Viscosity of magmatic liquids: A model, Earth Planet. Sc. Lett., 271, 123-134, https://doi.org/10.1016/j.epsl.2008.03.038, 2008.

Gonnermann, H. M. and Manga, M.: The Fluid Mechanics Inside a Volcano, Annu. Rev. Fluid Mech., 39, 321-356, https://doi.org/10.1146/annurev.fluid.39.050905.110207, 2007.

Goto, A.: A new model for volcanic earthquake at Unzen Volcano: Melt rupture model, Geophys. Res. Lett., 26, 2541-2544, 1999.

Gottsmann, J., Lavallée, Y., Martí, J., and Aguirre-Díaz, G.: Magma-tectonic interaction and the eruption of silicic batholiths, Earth Planet. Sc. Lett., 284, 426-434, https://doi.org/10.1016/j.epsl.2009.05.008, 2009.

Griffiths, L., Heap, M. J., Xu, T., Chen, C., and Baud, P.: The influence of pore geometry and orientation on the strength and stiffness of porous rock, J. Struct. Geol., 96, 149-160, https://doi.org/10.1016/j.jsg.2017.02.006, 2017.

Hale, A. J. and Wadge, G.: The transition from endogenous to exogenous growth of lava domes with the development of shear bands, J. Volcanol. Geoth. Res., 171, 237-257, https://doi.org/10.1016/j.jvolgeores.2007.12.016, 2008.

Harris, A. J. L., Flynn, L. P., Matías, O., and Rose, W. I.: The thermal stealth flows of Santiaguito dome, Guatemala?: Implications for the cooling and emplacement of dacitic block-lava flows, GSA Bull., 5, 533-546, 2002.

Heap, M. J. and Faulkner, D. R.: Quantifying the evolution of static elastic properties as crystalline rock approaches failure, Int. J. Rock Mech. Min., 45, 564-573, https://doi.org/10.1016/j.ijrmms.2007.07.018, 2008.

Heap, M. J., Vinciguerra, S., and Meredith, P. G.: The evolution of elastic moduli with increasing crack damage during cyclic stressing of a basalt from Mt. Etna volcano, Tectonophysics, 471, 153160, https://doi.org/10.1016/j.tecto.2008.10.004, 2009.

Heap, M. J., Faulkner, D. R., Meredith, P. G., and Vinciguerra, S.: Elastic moduli evolution and accompanying stress changes with increasing crack damage: Implications for stress changes around fault zones and volcanoes during deformation, Geo- phys. J. Int., 183, 225-236, https://doi.org/10.1111/j.1365246X.2010.04726.x, 2010.

Heap, M. J., Lavallée, Y., Laumann, A., Hess, K., Meredith, P. G., and Dingwell, D. B.: How tough is tuff in the event of fire?, Geology, 40, 311-314, https://doi.org/10.1130/G32940.1, 2012.

Heap, M. J., Lavallée, Y., Laumann, A., Hess, K., Meredith, P. G., Dingwell, D. B., Huismann, S. and Weise, F.: The influence of thermal-stressing (up to $1000^{\circ} \mathrm{C}$ ) on the physical, mechanical, and chemical properties of siliceous-aggregate, high-strength concrete, Constr. Build. Mater., 42, 248-265, https://doi.org/10.1016/j.conbuildmat.2013.01.020, 2013a.

Heap, M. J., Mollo, S., Vinciguerra, S., Lavallée, Y., Hess, K., Dingwell, D. B., Baud, P., and Iezzi, G.: Thermal weakening of the carbonate basement under Mt. Etna volcano (Italy): Implications for volcano instability, J. Volcanol. Geoth. Res., 250, 42-60, https://doi.org/10.1016/j.jvolgeores.2012.10.004, $2013 \mathrm{~b}$.

Heap, M. J., Lavallée, Y., Petrakova, L., Baud, P., Reuschlé, T., Varley, N. R., and Dingwell, D. B.: Microstructural controls on the physical and mechanical properties of edifice-forming andesites at Volcán de Colima, Mexico, J. Geophys. Res.-Sol. Ea., 119, 2925-2963, https://doi.org/10.1002/2013JB010521, 2014a.

Heap, M. J., Xu, T., and Chen, C.: The influence of porosity and vesicle size on the brittle strength of volcanic rocks and magma, B. Volcanol., 76, 856, https://doi.org/10.1007/s00445-014-08560, 2014b.

Heap, M. J., Farquharson, J. I., and Kolzenburg, S.: Timescales for permeability reduction and strength recovery in densifying magma, Earth Planet. Sc. Lett., 429, 223-233, https://doi.org/10.1016/j.eps1.2015.07.053, 2015.

Heap, M. J., Russell, J. K., and Kennedy, L. A.: Mechanical behaviour of dacite from Mount St. Helens (USA): A link between porosity and lava dome extrusion mechanism (dome or spine)?, J. Volcanol. Geoth. Res., 328, 159-177, https://doi.org/10.1016/j.jvolgeores.2016.10.015, 2016a.

Heap, M. J., Wadsworth, F. B., Xu, T., Chen, C., and Tang, C.: The strength of heterogeneous volcanic rocks: A 2D approximation, J. Volcanol. Geoth. Res., 319, 1-11, https://doi.org/10.1016/j.jvolgeores.2016.03.013, 2016b.

Heilprin, A.: Mont Pelée and the Tragedy of Martinique: A Study of the Great Catastrophes of 1902, with Observations and Experiences in the Field, J. B. Lippincott Company, Philadelphia, USA, London, UK, 1903.

Hess, K., Cordonnier, B., Lavallée, Y., and Dingwell, D. B.: Viscous heating in rhyolite: An in situ experimental determination, Earth Planet. Sc. Lett., 275, 121-126, https://doi.org/10.1016/j.epsl.2008.08.014, 2008.

Hoek, E. and Bieniawski, Z. T.: Brittle Rock Fracture Propagation In Rock Under Compression Brittle Rock Fracture Propagation in Rock Under Compression, Int. J. Fract. Mech., 1, 137-155, https://doi.org/10.1007/BF00186851, 1965.

Hornby, A. J., Kendrick, J. E., Lamb, O. D., Hirose, T., De Angelis, S. H., Von Aulock, F. W., Umakoshi, K., Miwa, T., Henton De Angelis, S., Wadsworth, F. B., Hess, K., Dingwell, D. B., and Lavallée, Y.: Spine growth and seismogenic faulting at Mt. Unzen, Japan, J. Geophys. Res.-Sol. Ea., 120, 4034-4054, https://doi.org/10.1002/2014JB011660, 2015.

ISRM Turkish National Group: The ISRM Suggested Methods for Rock Characterization, Testing and Monitoring: 2007-2014, 
edited by: R. Ulusay, Springer International, Ankara, Turkey, 2015.

Jahangiri, P., Streblow, R., and Müller, D.: Simulation of NonNewtonian Fluids using Modelica, Proc. 9th Int. Model. Conf., 3-5 September 2012, Aachen, Germany, 57-62, https://doi.org/10.3384/ecp1207657, 2012.

Kendrick, J. E., Lavallée, Y., Ferk, A., Perugini, D., Leonhardt, R., and Dingwell, D. B.: Extreme frictional processes in the volcanic conduit of Mount St. Helens (USA) during the 2004-2008 eruption, J. Struct. Geol., 38, 61-76, https://doi.org/10.1016/j.jsg.2011.10.003, 2012.

Kendrick, J. E., Smith, R., Sammonds, P., Meredith, P. G., Dainty, M., and Pallister, J. S.: The influence of thermal and cyclic stressing on the strength of rocks from Mount St. Helens, Washington, B. Volcanol., 75, 1-12, https://doi.org/10.1007/s00445-0130728-z, 2013a.

Kendrick, J. E., Lavallée, Y., Hess, K., Heap, M. J., Gaunt, H. E., Meredith, P. G., and Dingwell, D. B.: Tracking the permeable porous network during strain-dependent magmatic flow, J. Volcanol. Geoth. Res., 260, 117-126, https://doi.org/10.1016/j.jvolgeores.2013.05.012, 2013b.

Kendrick, J. E., Lavallée, Y., Mariani, E., Dingwell, D. B., Wheeler, J., and Varley, N. R.: Crystal plasticity as an indicator of the viscous-brittle transition in magmas, Nat. Commun., 8, 1926, https://doi.org/10.1038/s41467-017-01931-4, 2017.

Kohashi, S., Shimokawa, S., Shimizu, K., Satohira, Y., Yamada, T., and Kimura, T.: Document for the committee of survey and countermeasure on lava dome collapse in Unzen Volcano, Futenma lava dome collapse Discussion materials; Investigation, Observation and countermeasure study committee on Unzen, 28 March 2012, Shimabara-shi Uto-cho, 2012 (in Japanese).

Kolzenburg, S., Heap, M. J., Lavallée, Y., Russell, J. K., Meredith, P. G., and Dingwell, D. B.: Strength and permeability recovery of tuffisite-bearing andesite, Solid Earth, 3, 191-198, https://doi.org/10.5194/se-3-191-2012, 2012.

Kueppers, U., Scheu, B., Spieler, O., and Dingwell, D. B.: Field-based density measurements as tool to identify preeruption dome structure: set-up and first results from Unzen volcano, Japan, J. Volcanol. Geoth. Res., 141, 65-75, https://doi.org/10.1016/j.jvolgeores.2004.09.005, 2005.

Kushnir, A. R. L., Martel, C., Bourdier, J.-L., Heap, M. J., Reuschlé, T., Erdmann, S., Komorowski, J.-C., and Cholik, N.: Probing permeability and microstructure: Unravelling the role of a low-permeability dome on the explosivity of Merapi (Indonesia), J. Volcanol. Geoth. Res., 316, 56-71, https://doi.org/10.1016/j.jvolgeores.2016.02.012, 2016.

Kushnir, A. R. L., Martel, C., Champallier, R., and Arbaret, L.: In situ confirmation of permeability development in shearing bubble-bearing melts and implications for volcanic outgassing, Earth Planet. Sc. Lett., 458, 315-326, https://doi.org/10.1016/j.epsl.2016.10.053, 2017.

Lamb, O. D., De Angelis, S., Umakoshi, K., Hornby, A. J., Kendrick, J. E., and Lavallée, Y.: Repetitive fracturing during spine extrusion at Unzen volcano, Japan, Solid Earth, 6, 12771293, https://doi.org/10.5194/se-6-1277-2015, 2015.

Lamb, O. D., Angelis, S. De, Wall, R. J., Lamur, A., Varley, N. R., Reyes-Dávila, G., Arámbula-Mendoza, R., Hornby, A. J., Kendrick, J. E., and Lavallée, Y.: Seismic and experimental insights into eruption precursors at
Volcán de Colima, Geophys. Res. Lett., 44, 6092-6100, https://doi.org/10.1002/2017GL073350, 2017.

Lamur, A., Kendrick, J. E., Eggertsson, G. H., Wall, R. J., Ashworth, J. D., and Lavallée, Y.: The permeability of fractured rocks in pressurised volcanic and geothermal systems, Sci. Rep., 7, 6173, https://doi.org/10.1038/s41598-017-05460-4, 2017.

Lamur, A., Lavallée, Y., Iddon, F. E., Hornby, A. J., Kendrick, J. E., Von Aulock, F. W., and Wadsworth, F. B.: Disclosing the temperature of columnar jointing in lavas, Nat. Commun., 9, 1432, https://doi.org/10.1038/s41467-018-03842-4, 2018.

Laumonier, M., Arbaret, L., Burgisser, A., and Champallier, R.: Porosity redistribution enhanced by strain localization in crystal-rich magmas, Geology, 39, 715-718, https://doi.org/10.1130/G31803.1, 2011.

Lavallée, Y., Hess, K., Cordonnier, B., and Dingwell, D. B.: NonNewtonian rheological law for highly crystalline dome lavas, Geology, 35, 843-846, https://doi.org/10.1130/G23594A.1, 2007.

Lavallée, Y., Meredith, P. G., Dingwell, D. B., Hess, K., Wassermann, J., Cordonnier, B., Gerik, A., and Kruhl, J. H.: Seismogenic lavas and explosive eruption forecasting, Nature, 453, 507510, https://doi.org/10.1038/nature06980, 2008.

Lavallée, Y., Varley, N. R., Alatorre-Ibargüengoitia, M. a., Hess, K., Kueppers, U., Mueller, S. P., Richard, D., Scheu, B., Spieler, O., and Dingwell, D. B.: Magmatic architecture of dome-building eruptions at Volcán de Colima, Mexico, B. Volcanol., 74, 249260, https://doi.org/10.1007/s00445-011-0518-4, 2012.

Lavallée, Y., Heap, M. J., Kueppers, U., Kendrick, J. E., and Dingwell, D. B.: The fragility of Volcán de Colima - a material constraint, in: Volcán de Colima: portrait of a persistently hazardous volcano, edited by: Varley, N. R., Connor, C. B., and Komorowski, J. C., Springer, Berlin, Germany, 2018.

Lejeune, A. M. and Richet, P.: Rheology of crystal-bearing silicate melts?: An experimental study at high viscosities, J. Geophys. Res., 100, 4215-4229, 1995.

Lejeune, A. M., Bottinga, Y., Trull, T. W., and Richet, P.: Rheology of bubble-bearing magmas, Earth Planet. Sc. Lett., 166, 71-84, https://doi.org/10.1016/S0012-821X(98)00278-7, 1999.

Llewellin, E. W. and Manga, M.: Bubble suspension rheology and implications for conduit flow, J. Volcanol. Geoth. Res., 143, 205217, https://doi.org/10.1016/j.jvolgeores.2004.09.018, 2005.

Lopez, D. L. and Williams, S. N.: Catastrophic Volcanic Collapse: Relation to Hydrothermal Processes, Science, 260, 1794-1796, https://doi.org/10.1126/science.260.5115.1794, 1993.

Mader, H. M., Llewellin, E. W., and Mueller, S. P.: The rheology of two-phase magmas: A review and analysis, J. Volcanol. Geoth. Res., 257, 135-158, https://doi.org/10.1016/j.jvolgeores.2013.02.014, 2013.

Manga, M., Castro, J. M., Cashman, K. V., and Lowewenberg, M.: Rheology of bubble-bearing magmas, J. Volcanol. Geoth. Res., 87, 15-28, 1998.

Martel, C. and Schmidt, B. C.: Decompression experiments as an insight into ascent rates of silicic magmas, Contrib. Mineral. Petr., 144, 397-415, https://doi.org/10.1007/s00410-002-0404-3, 2003.

Matsushima, T. and Takagi, A.: GPS and EDM monitoring of Unzen Volcano ground deformation, Earth Planets Space, 52, 1015$1018,2000$. 
Maxwell, J. C.: On the dynamical theory of gases, Philos. T. Roy. Soc. Lond., 157, 49-88, https://doi.org/10.1098/rstl.1867.0004, 1867.

McKenzie, D. and Holness, M.: Local deformation in compacting flows: Development of pressure shadows, Earth Planet. Sc. Lett., 180, 169-184, https://doi.org/10.1016/S0012-821X(00)00152-7, 2000.

Mueller, S., Melnik, O., Spieler, O., Scheu, B., and Dingwell, D. B.: Permeability and degassing of dome lavas undergoing rapid decompression: An experimental determination, B. Volcanol., 67, 526-538, https://doi.org/10.1007/s00445-004-0392-4, 2005.

Mueller, S., Scheu, B., Kueppers, U., Spieler, O., Richard, D., and Dingwell, D. B.: The porosity of pyroclasts as an indicator of volcanic explosivity, J. Volcanol. Geoth. Res., 203, 168-174, https://doi.org/10.1016/j.jvolgeores.2011.04.006, 2011a.

Mueller, S., Llewellin, E. W., and Mader, H. M.: The effect of particle shape on suspension viscosity and implications for magmatic flows, Geophys. Res. Lett., 38, 1-5, https://doi.org/10.1029/2011GL047167, 2011b.

Nakada, S. and Fujii, T.: Preliminary report on the activity at Unzen Volcano (Japan), November 1990-November 1991: Dacite lava domes and pyroclastic flows, J. Volcanol. Geoth. Res., 54, 319333, https://doi.org/10.1016/0377-0273(93)90070-8, 1993.

Nakada, S. and Motomura, Y.: Petrology of the 1991-1995 eruption at Unzen: Effusion pulsation and groundmass crystallization, J. Volcanol. Geoth. Res., 89, 173-196, https://doi.org/10.1016/S0377-0273(98)00131-0, 1999.

Nakada, S., Miyake, Y., Sato, H., Oshima, O., and Fujinawa, A.: Endogenous growth of dacite dome at Unzen volcano (Japan), 1993-1994, Geology, 23, 157-160, https://doi.org/10.1130/00917613(1995)023<0157:EGODDA>2.3.CO;2, 1995.

Nakada, S., Shimizu, H. and Ohta, K.: Overview of the 1990-1995 eruption at Unzen Volcano, J. Volcanol. Geoth. Res., 89, 1-22, https://doi.org/10.1016/S0377-0273(98)00118-8, 1999.

NASA/METI/AIST/Japan Spacesystems, and U.S./Japa. A. S. T.: NASA EOSDIS Land Processes DAAC ASTER, DEM Prod. N032E130, https://doi.org/10.5067/ASTER/AST14DEM.003, 2001.

Ostwald, W.: Concerning the function rate of the viscosity of dispersion systems, 36, 248-250, 1925.

Pallister, B. J. S., Thornber, C. R., Cashman, K. V., Clynne, M. A., Lowers, H. A., Mandeville, C. W., Brownfield, I. K., and Meeker, G. P.: Petrology of the 2004-2006 Mount St. Helens Lava Dome - Implications for Magmatic Plumbing and Eruption Triggering, in: A Volcano Rekindled: The Renewed Eruption of Mount St. Helens 2004-2006, U.S. Geological Survey Professional Paper 1750, edited by: Sherrod, D. R., Scott, W. E., and Stauffer, P. H., USGS, Reston, VA, USA, 647-702, 2008.

Paterson, M. S. and Wong, T.-F.: Experimental Rock Deformation: The Brittle Field, 2nd edn., Springer, Berlin Heidelberg, Germany, 2005.

Pierson, T. C., Janda, R. J., Thouret, J.-C., and Borrero, C. A.: Perturbation and melting of snow and ice by the 13 November 1985 eruption of Nevado del Ruiz, Colombia, and consequent mobilization, flow and deposition of lahars, J. Volcanol. Geoth. Res., 41, 17-66, 1990.

Pola, A., Crosta, G., Fusi, N., Barberini, V., and Norini, G.: Influence of alteration on physical properties of volcanic rocks, Tectonophysics, 566-567, 67-86, https://doi.org/10.1016/j.tecto.2012.07.017, 2012.

Quane, S. L. and Russell, J. K.: Welding: insights from hightemperature analogue experiments, J. Volcanol. Geoth. Res., 142, 67-87, https://doi.org/10.1016/j.jvolgeores.2004.10.014, 2005.

Reid, M. E., Keith, T. E. C., Kayen, R. E., Iverson, N. R., Iverson, R. M., and Brien, D. L.: Volcano collapse promoted by progressive strength reduction: New data from Mount St. Helens, B. Volcanol., 72, 761-766, https://doi.org/10.1007/s00445-0100377-4, 2010.

Reiner, M.: The Deborah Number, Phys. Today, 17, 62, https://doi.org/10.1063/1.3051374, 1964.

Roscoe, R.: The viscosity of suspensions of rigid spheres, Br. J. Appl. Phys., 3, 267-269, https://doi.org/10.1088/05083443/3/8/306, 1952.

Rust, A. C. and Manga, M.: Effects of bubble deformation on the viscosity of dilute suspensions, J. Non-Newton. Fluid, 104, 5363, 2002.

Sakuma, S., Kajiwara, T., Nakada, S., Uto, K., and Shimizu, H.: Drilling and logging results of USDP4 - Penetration into the volcanic conduit of Unzen Volcano, Japan, J. Volcanol. Geoth. Res., 175, 1-12, https://doi.org/10.1016/j.jvolgeores.2008.03.039, 2008.

Sammis, C. G. and Ashby, M. F.: The failure of brittle porous solids under compressive stress states, Acta Metall., 34, 511-526, 1986.

Schaefer, L. N., Kendrick, J. E., Oommen, T., Lavallée, Y., and Chigna, G.: Geomechanical rock properties of a basaltic volcano, Front. Earth Sci., 3, 1-15, https://doi.org/10.3389/feart.2015.00029, 2015.

Scholz, C. H.: Microfracturing and the inelastic deformation of rock in compression, J. Geophys. Res., 73, 1417, https://doi.org/10.1029/JB073i004p01417, 1968.

Scott, W. E., Sherrod, D. R., and Gardner, C. A.: Overview of the 2004 to 2006, and continuing, eruption of Mount St. Helens, Washington, in: A Volcano Rekindled: The Renewed Eruption of Mount St. Helens, 2004-2006, U.S. Geological Survey Professional Paper 1750, vol. 1750, 3-22, edited by: Sherrod, D. R., Scott, W. E., and Stauffer, P. H., available at: http://pubs.usgs. gov/pp/1750/chapters/pp2008-1750_chapter01.pdf (last access: 30 October 2018), 2008.

Siebert, L., Glicken, H., and Ui, T.: Volcanic hazards from Bezymianny- and Bandai-type eruptions, B. Volcanol., 49, 435459, https://doi.org/10.1007/BF01046635, 1987.

Siebert, L., Cottrell, E., Venzke, E., and Andrews, B.: Earth's Volcanoes and Their Eruptions: An Overview, in: The Encyclopedia of Volcanoes, edited by: Sigurdsson, H., Houghton, B. F., McNutt, S., Rymer, H., and Stix, J., Elsevier, Academic Press, London UK, 239-256, 2015.

Smith, R., Kilburn, C. R. J., and Sammonds, P. R.: Rock fracture as a precursor to lava dome eruptions at Mount St. Helens from June 1980 to October 1986, B. Volcanol., 69, 681-693, https://doi.org/10.1007/s00445-006-0102-5, 2007.

Smith, R., Sammonds, P. R., Tuffen, H., and Meredith, P. G.: Evolution of the mechanics of the 2004-2008 Mt. St. Helens lava dome with time and temperature, Earth Planet. Sc. Lett., 307, 191-200, https://doi.org/10.1016/j.epsl.2011.04.044, 2011.

Sparks, R. S. J.: Causes and consequences of pressurisation in lava dome eruptions, Earth Planet. Sc. Lett., 150, 177-189, https://doi.org/10.1016/S0012-821X(97)00109-X, 1997. 
Sparks, R. S. J. and Young, S. R.: The eruption of Soufrière Hills Volcano, Montserrat (1995-1999): overview of scientific results, in: The Eruption of Soufrire Hills Volcano, Montserrat, from 1995 to 1999, edited by: Druitt, T. H. and. Kokelaar, B. P, Geological Society, London, Memoirs, UK, 45-69, 2002.

Stasiuk, M. V. and Jaupart, C.: Lava flow shapes and dimensions as reflections of magma system conditions, J. Volcanol. Geoth. Res., 78, 31-50, https://doi.org/10.1016/S0377-0273(97)000024, 1997.

Surono, Jousset, P., Pallister, J., Boichu, M., Buongiorno, M. F., Budisantoso, A., Costa, F., Andreastuti, S., Prata, F., Schneider, D., Clarisse, L., Humaida, H., Sumarti, S., Bignami, C., Griswold, J., Carn, S., Oppenheimer, C., and Lavigne, F.: The 2010 explosive eruption of Java's Merapi volcano-A “100-year" event, J. Volcanol. Geoth. Res., 241-242, 121-135, https://doi.org/10.1016/j.jvolgeores.2012.06.018, 2012.

Takarada, S., Miyabuchi, Y., Hoshizumi, H., Matsushima, T., and Nagai, D.: A02: Unzen and Aso volcanoes, central Kyushu, Japan: Unzen's new lava dome climb and 1991-95 poyroclastic flows and Aso's active crater and one of the largest calderas in Japan, Proc. IAVCEI Conf. Field trip guide, 20-24 July 2013, Kagoshima, Japan, 2013.

Tanguy, J. C.: Rapid dome growth at Montagne Pelée during the early stages of the 1902-1905 eruption: A reconstruction from Lacroix's data, B. Volcanol., 66, 615-621, https://doi.org/10.1007/s00445-004-0344-z, 2004.

Truby, J. M., Mueller, S. P., Llewellin, E. W., and Mader, H. M.: The rheology of three-phase suspensions at low bubble capillary number, Proc. Math. Phys. Eng. Sci., 471, 20140557, https://doi.org/10.1098/rspa.2014.0557, 2015.

Umakoshi, K., Takamura, N., Shinzato, N., Uchida, K., Matsuwo, N., and Shimizu, H.: Seismicity associated with the 1991-1995 dome growth at Unzen Volcano, Japan, J. Volcanol. Geoth. Res., 175, 91-99, https://doi.org/10.1016/j.jvolgeores.2008.03.030, 2008.

Vallance, J. W., Schneider, D. J., and Schilling, S. P.: Growth of the 2004-2006 Lava-Dome Complex at Mount St. Helens, Washington, in: A Volcano Rekindled: The Renewed Eruption of Mount St. Helens 2004-2006, edited by: Sherrod, D. R., Scott, W. E., and Stauffer, P. H., U.S. Geological Survey Professional Paper 1750, USGS, Reston, VA, USA, 169-208, 2008.

Venezky, D. Y. and Rutherford, M. J.: Petrology and Fe-Ti oxide reequilibration of the 1991 Mount Unzen mixed magma, J. Volcanol. Geoth. Res., 89, 213-230, https://doi.org/10.1016/S03770273(98)00133-4, 1999.

Voight, B.: Structural stability of andesite volcanoes and lava domes, Philos. T. R. Soc. Lond., 358, 1663-1703, https://doi.org/10.1098/rsta.2000.0609, 2000.

Voight, B. and Elsworth, D.: Failure of volcano slopes, Geotechnique, 47, 1-31, 1997.

Voight, B. and Elsworth, D.: Instability and collapse of hazardous gas-pressurized lava domes, Geophys. Res. Lett., 27, 1-4, 2000.

Voight, B., Glicken, H., Janda, J., and Douglass, P. M.: Catastrophic rockslide avalanche of May 18, in: The 1980 eruptions of Mount St Helens, Washington, vol. 1250, 347-378, edited by: Lipman, P. W. and Mullineaux, D. R., Geological Survey Professional Paper, U.S. G.P.O., Washington, DC, USA, 1981.
Voight, B., Sparks, R. S. J., Miller, A. D., Stewart, R. C., Hoblitt, R. P., Clarke, A., Ewart, J., Aspinall, W. P., Baptie, B., Calder, E. S., Cole, P. D., Druitt, T. H., Hartford, C., Herd, R. A., Jackson, P., Lejeune, A. M., Lockhart, A. B., Loughlin, S. C., Luckett, R., Lynch, L., Norton, G. E., Robertson, R., Watson, I. M., Watts, R., and Young, S. R.: Magma Flow Instability and Cyclic Activity at Soufriere Hills Volcano, Montserrat, British West Indies, Science, 283, 1138-1142, https://doi.org/10.1126/science.283.5405.1138, 1999.

Vona, A., Romano, C., Dingwell, D. B., and Giordano, D.: The rheology of crystal-bearing basaltic magmas from Stromboli and Etna, Geochim. Cosmochim. Ac., 75, 3214-3236, https://doi.org/10.1016/j.gca.2011.03.031, 2011.

Vona, A., Romano, C., Giordano, D., and Russell, J. K.: The multiphase rheology of magmas from Monte Nuovo (Campi Flegrei, Italy), Chem. Geol., 346, 213-227, https://doi.org/10.1016/j.chemgeo.2012.10.005, 2013.

Wadsworth, F. B., Witcher, T., Vasseur, J., Dingwell, D. B., and Scheu, B.: When Does Magma Break?, in: Advances in Volcanology, Springer, Berlin, Heidelberg, Germany, 2017.

Wallace, P. A., Kendrick, J. E., Ashworth, J. D., Coats, R., Lamb, O., Miwa, T., Mariani, E., and Lavallée, Y.: The influence of strain localisation on spine extrusion dynamics during the 1991-1995 eruption at Unzen volcano (Japan), Proc. 19th EGU General Assembly, 23-28 April 2017, Vienna, Austria, 17258, 2017EGUGA..1917258W, 2017.

Walter, T. R., Troll, V. R., Cailleau, B., Belousov, A., Schmincke, H. U., Amelung, F., and Bogaard, P.: Rift zone reorganization through flank instability in ocean island volcanoes: An example from Tenerife, Canary Islands, B. Volcanol., 67, 281-291, https://doi.org/10.1007/s00445-004-0352-z, 2005.

Webb, S. L. and Dingwell, D. B.: The onset of non-Newtonian rheology of silicate melts - A fiber elongation study, Phys. Chem. Miner., 17, 125-132, https://doi.org/10.1007/BF00199663, 1990.

Webb, S. L. and Knoche, R.: The glass-transition, structural relaxation and shear viscosity of silicate melts, Chem. Geol., 128, 165-183, https://doi.org/10.1016/0009-2541(95)00171-9, 1996.

Yamamoto, T., Takarada, S., and Suto, S.: Pyroclastic flows from the 1991 eruption of Unzen volcano, Japan, B. Volcanol., 55, 166175, https://doi.org/10.1007/BF00301514, 1993.

Young, S. R., Sparks, R. S. J., Aspinall, W. P., Lynch, L. L., Miller, A. D., Robertson, R. E. A., and Shepherd, J. B.: Overview of the eruption of Soufriere Hills Volcano, Montserrat, 18 July 1995 to December 1997, Geophys. Res. Lett., 25, 3389-3392, https://doi.org/10.1029/98GL01405, 1998.

Zhu, W., Baud, P., and Wong, T.-F.: Micromechanics of cataclastic pore collapse in limestone, J. Geophys. Res.-Sol. Ea., 115, B04405, https://doi.org/10.1029/2009JB006610, 2010. 